KINESIS, SWNA MARIA, $N^{\circ} 25,2007$.

\title{
CONSTRUINDO COM IDOSOS PERSPECTIVAS DE UMA EDUCAÇÃO PERMANENTE
}

\author{
CEOLIN, Cláudia Elisa Grasel; DIAS, José Francisco Silva
}

\section{RESUMO}

O objetivo deste estudo foi buscar caminhos para uma reflexão de uma ação pedagógica visando uma Educação Física Permanente, baseada nas significações desveladas através dos depoimentos temáticos de vida dos idosos participantes dos projetos do NIEATI. No primeiro capítulo apresentamos as razões da investigação. incluindo minha trajetória pessoal relacionada com a temática: os fenomenos do envelhecimento populacional e da transição demográfica e minha caminhada acadêmica. No segundo capitulo mergulhamos em uma incursio té́rica que passa por aspectos relativos a sociedade. Educaçoo Física. compreensōes de corpo movimento e oque denominamos competéncias para bem viver. No terceiro capitulo estäo registrados os procedimentos metodológicos do estudo. Utilizamos a metodologia da Historia Oral temática. Como instrumentos de pesquisa utilizamos entrevista temática e caderno de campo. A colônia do estudo. que representa uma coletividade de destino demarcada, foi constituída por Idosos matriculados nos programas do NIEATI há mais de cinco anos. A seleção dos colaboradores foi através de rede, sendo a amostra constituída de quatro colaboradoras do sexo feminino, com idades entre 62 e 79 anos de idade. Para a análise das informaçōes utilizamos categorias de análise a partir de três cortes horizontais temporais temáticos relativos a manifestações de movimento, que correspondem respectivamente a: juventude, vida adulta e velhice. No quarto capítulo convocamos as colaboradoras do estudo, os autores e os leitores para a discussão temática proposta. As manifestaçōes de movimento nas histórias de vida e a literatura consultada neste estudo nos remetem a reflexão das concepções de corpo e movimento, bem como das subordinações históricas da Educação Física. No quinto capítulo estão as verdades provisórias refletidas neste estudo. Concluímos que a fundamentaçāo de uma Educação Física, que se pretende permanente deve obedecer, mesmo que provisoriamente ao paradigma da reflexão fenomenológica do movimento. A partir deste, podemos considerar alguns princípios norteadores de nossas opções pedagógicas. São eles; concepção de homem enquanto ser histórico-cultural, inacabado, com biografia pessoal; educação enquanto evento permanente na existência humana; corpo/corporeidade enquanto o modo de ser e estar no mundo; movimento como um diálogo do homem com o mundo; aprendizagem enquanto 'resultado' da disputa subjetiva travada através experiência na busca do desenvolvimento do que denominamos de competências do bem viver. Torna-se fundamental pensar uma educação Física permanente que ultrapasse os 
muros das escolas e adentre na vida das pessoas, em todas as idades. Almejamos que as discussôes se ampliem e questōes relacionadas com envelhecimento humano, e também com a vida adulta figurem naturalmente no contexto geral das propostas de Educaçāo Física.

Unmrernos: Educação Física Permanente, idosos, açāo pedagógica

\title{
CONSTRUCTING WITH SENIORS PERSPECTIVES TO ONE PHYSICAL EDUCATION PERMANENT
}

\begin{abstract}
The objective of this paper went look for roads for a reflection of a pedagogic action seeking a Permanen Physical Education, based on the significances watched through the thematic depositions of the senions purticipants of the projects of NIEATI life. In the firs chapter we prescnted die reasons or the investigation, including my personal trajectory related with the thematic: the phenomenons of the aging populacional and of the demographic transition and my academic walk. In the second chapter we plunged in a theoretical incursion that it goes by relative aspects the society. Physical Education, body understandings and movement and what denominated competences for well to live. In the third chapter the methodological procedures of the study are registered. We used the methodology of the thematic Oral History. As research instruments used thematic interview and field notebook. The colony of the study, that it represents a demarcated destiny collective, it was constituted by Seniors registered in the programs of NIEATI there is more than five years. The collaborators' selection was through net, being the four collaborators' of the feminine sex constituted sample, with ages between 62 and 79 years of age. For the analysis of the information we used analysis categories starting from three courts horizontal relative thematic storms to movement manifestations, that correspond the respectively: youth, adult life and age. In the fourth chapter we summoned the collaborators of the study, the authors and the readers for the discussion thematic proposal. The movement manifestations in the life histories and the literature consulted in this study send us the reflection of the body conceptions and movement, as well as of the historical subordinations of the Physical Education. In the fifth chapter they are the truths provisórias contemplated in this study. We ended that the fundamentação of a Physical Education, that is intended permanent it should obey, even if provisorily to the paradigm of the reflection fenomenológica of the movement. Starting from this, we can consider some beginnings norteadores of our pedagogic options. They are them: man's conception while to be historical-cultural, unfinished, with personal biography; education while permanent event in the human existence; corpo/corporeidade
\end{abstract}


while the way of to be and to be in the world; I move as a dialogue of the man with the world; learning while 'result ' of the subjective dispute joined experience through in the search of the development than we denominated of competences of the good to live. He/ she becomes fundamental to think a permanent Physical education that surpasses the walls of the schools and penetrate in the people's life, in all the ages. We longed for that the discussions are enlarged and subjects related with human aging. and also with the adult life they represent naturally in the general context of the proposals of PhysicalEducation.

Unrternis: Permanent Physical Education: old-aged; Pedagogical action

\section{AS RAZÕES DA BUSCA}

Estarmoscientes do contex to social e histórico onde o tema de estudo está inerso É fundumental paru compreendermos as interferências do contex to du especificidade de intervençāo e açầ. E mais. investigarmos acerca do "fazer". em busca constante por nowals opcóes pedagogicas. requer dialogo, que por sua vez como coloca FREIRE 1987 \% requer uma intensa fé nos homens, fé no seu poder de fazer e refazer, de criar e recriar, e isto posto como um direito de todos os homens.

Imbricados desta compreensão, entendemos como fundamental fazer algumas considerações nesta fase de estudo. Vivemos um momento histórico. importante no que diz respeito aos indivíduos mais velhos. Histórico por duas razc̃es bem pontuadas, que também se encontram relacionadas entre si. A primeira razão é demonstrada pelas estatísticas populacionais que indicam ser crescente o segmento populacional de idosos no mundo, e o quanto este fato tem implicaçōes práticas na estrutura social. A segunda razãoé traduzida pelo que denomino de "movimentos da terceira idade", os quais nasceram da necessidade coletiva de resgatar e talvez até redimensionar o papel do velho em nossa sociedade. Este movimento transparece aos olhos através dos grupos de convivência da terceira idade que surgem a cada dia, pelos programas de universidades para terceira idade, a efetiva participação em grupos de atividades físicas, sociais, o engajamento em propostas de ações sociais. enfim, os velhos unindo-se e conquistando novos espaços, novos papéis, um novo tempo.

A sociedade como um todo tem a necessidade e o dever de "olhar" para os mais velhos e neste contexto a Educação Física também possui responsabilidades na busca de uma sociedade que trate a velhice com mais dignidade. Seria ingenuidade pensar que a prática da Educação Física poderia resolver todos os problemas relacionados com as questōes do envelhecimento na sociedade contemporânea, mas é a fatia que lhe compete na caminhada em busca de um novo tempo.

Portanto, este novo contex to exige dos educadores redimensionar e refletir as 
propostas pedagógicas, a fim de evoluir juntamente com as transformações pelas quăis nossa sociedade passa, bem como trabalhar em prol destas transformações. A maneira de contribuir é caminhar lado a lado com e para a transformação da realidade e esta se materializa através da pesquisá e da discussão

\section{Algumas compreensões essenciais}

Considerando o contexto, já referido anteriormente. e refletindo acerca da questão explicitada acima, precisamos considerar que consciente ou inconscientemente nos encontramos enquanto professores de Educação Física envolvidos no que TREBELS (1998) chamou de rede de relaçōes de concepções pedagógicas. A opção pedagógica e as concepcones de homem e sociedade são deteminantes em nosua atuaçũo intervenção junto aos educandos. O autor afirma que antes de tudo precisamos ter uma concepcão humana que atêta diretamente na concepção de educaçăo e de movimento. que. por sua vez. em umat redidade micro influencia a concepção da sociedade formando assim uma rede que norteia a pratica ou anda nossa prixis.

Essus concepçôes de homem, sociedade. educação movimento, citadas por Trebels (1998) tornam-se as bases que fundamentam o exercício deste estudo. Discutir a rede de concepções que norteiam nossa práxis é fundamental para estabelecer propostas de ação e intervenção no âmbito educacional, aqui entendido na dimensão permanente do fenomeno educacional.

Consideramos o homen, ator de sua vida, sujeito de suas ações. que influencia a ordem social, que constrói sua cultura. interage e se relaciona com os demais sujeitos. Ser em constante construçāo, em desenvolvimento, em busca de seu acabamento.

Entendemos a sociedade como uma estrutura construída e em constante transformação mantida pelo homem, dependente da cultura e do momento histórico. Sociedade em crise, em busca de uma cultura emergente.

O mundo é compreendido enquanto um espaço onde o homem se faz homem constrói sua identidade, fundamenta a sociedade e sua cultura. É o palco de sua construção e desenvolvimento, espaço de vivênciase aprendizagens.

A complexidade da sociedade nos remete à idéia de rede de relaçōes, onde a presença no mundo nãoé uma experiência individualizadae "higiênica", mas sim oconfronto do que sou e do que é o outro, e das influências sociais, culturais e históricas. Este fatoé lembrado por Freire (1998, p.59) no trecho escrito a seguir.

“... percebo afinal que a construção de minha presença no mundo, que não se faz no isolamento, isenta da influência das forças sociais, que não se compreende fora da tensão entre o que herdo 
geneticamente e o que herdo social, culturale historicamente, tem muito a ver comigo mesmo". (FREIRE. 1998, p.59)

Caminhando para a discussão específica deste estudo, baseados no escrito até entāo, visłumbramos situaçōes geracionais que nos remetem a discutir papéis etários.

\section{Significações de velhice e envelhecimento}

A ordem social que apresenta os ciclos de vida aponta três segmentos claramente demarcados: a juventude, vinculada com a vida escolar, o mundo adulto com o trabalho: e a velhice com a aposentadoria. $\mathrm{O}$ apagamento das fronteiras que separavam estes três segmentos e das nomas ditadas para cada grupo etário, é de acordo com Moody apud Deben (1999. p.57). oreflexo de uma sociedade marcada pela informatização da economia. pela desmassificaçào dos mercados de consumo. da política da midia e da cuitura. e pela fluidez e multiplicidade de estilos de vida. frutos de umateconomia baseada mais no consumo do que na produtividade.

As transtomações na periodização do ciclo vital estão caminhando para um estilo unietário, que de acordo com Meyrowitz apud Debert( 1999.p. 19) é chamado de Sociedade unietária e corresponde ao impacto da mídia eletrônica no comportamento social.

A mídia. a literatura chamada de "auto-ajuda" e os teóricos da gerontologia e geriatria assumem um comum acordo de significação de velhice denominada entre os teóricos de velhice bem-sucedida. Esta é uma visão "positiva" da velhice que coloca a atividade no lugar de descanso com característica deste período da vida. São os signos sendo invertidos.

"Os signos do envelhecimento são invertidos e assumem novas designaçōes: 'nova juventude'. 'idade do lazer' Damesma forma. invertem-se os signos da aposentadoria, que deixa de ser um momento de descanso e recolhimento para tornar-se um período de atividade e lazer". (Debert, 1999, p.61)

Vale lembrar que na década de 70 ficou marcada pela 'Conspiraçāo do Silêncio", denúncia comandada por Simone de Beauvoir. Odiscurso teórico revelava uma significaçāo bem diversa do comentado no parágrafo anterior. Podemos observar tal afirmação nos trechos a seguir.

"Os interesses em jogo nessa luta não são apenas de ordem prática, mas também de ordem moral: queremos que os velhos se 
conformem à imagem que a sociedade faz deles. Imponos-lhes regras com relaçäora vestuário. una decència de maneiras, eum respeito às aparencias". (Beanvoir 1986, p.268)

Eainda.

"...quando o adulto nāo tem ligaçào pessod ann os relhos, estes suscitam nele un despre-o tingido de repulsa: vimos cono. ao longo dos séculos, os autores comicos exploravam este sentimento. $O$ homem idoso aparecendo ao mais joven como sua caricatura. este se diverte en caricatura-lo, a fin de the retirar a solidadriedade através do riso. Nesse ridiculo muitas vezes entra sadismo. Fiquei

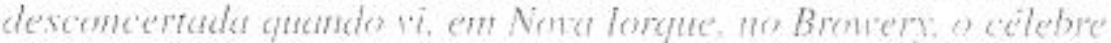
cabare onde canam e dancan. levantando as saias, hompleis actogenarias. O pubico fartara-se de rit: a que significara. na

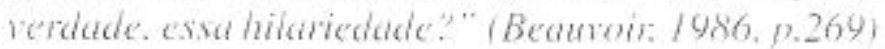

A discussäo de velhice, neste sentido. fica justificada quando nos deparamos com a situação de como o velho era tratado até então. Observamos a incredulidade nas realizaçôes dos mais velhos, e quando algum "velho" se sobressai com algum "feito", todos se admiram, pois vai contra a ordem preconceituosa da sociedade perceber a velhice.

Apontar as relaçồes do binômio que envolve velhice e sociedade deve constituir um fato estritamente teórico, uma vez que compreendemos que os velhos fazem parte da sociedade. Neste sentido, compactuamos com Andrade( 1999), onde a autora coloca:

"Sei bem que os velhos fazem parte da sociedade. colocar aqui este binomio é referir-me ao problema das relaçöes que o velho estabelece no sea interior, no total ou em alguma parte. em qualquer nivel e campo". (. p.79)

Historicamente, a temática do envelhecimento na sociedade vem traçando uma trajetória bem definida que Debert $(1999$, p.56) estabelece na sequiência.

"A histôria da civilização ocidental estaria, desse ponto de vista marcada por três etapas sucessivas em que a sensibilidade investida na idade cronológica é radicalmente distinta: a pré-modernidade. èn que a idade cronológica é menos relevante do que o status da família na determinaçấo do grau de maturidade e do controle de recursos de poder: a modenidade, que teria correspondido a uma

KINESIS, SANTA MIRIA, $N^{\circ} 25,200 I$ 
cronologižaçäo da vida; e a pós-modemidade. que operaria una desconstruçūo do carso da vida em nome de um estilo unietario". (Debert, 1999, p.56).

Sobre a compreensão de velhoe velhice, compreendemos enquanto um fenômeno natural quando vislumbrada pelo ponto de vista biológico, do declínio das lunçōes. das respostas fisiológicas dadas ao longo da vida. Estamos fadados a envelhecer, faz parte da ordem da natureza humana. Poderíamos citar Beauvoir(1990) quando ela coloca que salvo não morrermos antes, todos ficaremos velhos.

Por outro lado, a velhice pode ser considerada como um fenômeno cultural por assumir diferentes dimensōes e significados em diferentes sociedades e períodos históricos diferentes. Podemos inferir que ela é uma construçîo social.

Velho, idoso, ancião, geronte, senescente, em nossa compreensão é o sujeito que vive a velhice e seu conceito está intimamente ligado com a visāo/compreensão de velhice que possumos. Ser velho. ser crianca. ser jovem ou adulto. no meu entendimento é simplesmente ser homem. com todas as suas caracteristicas e possibilidades de desenvoivimento.

"A tendência contemporânea é rever os estereótipos associados ao envelhecimento. A idéia de um processo de perdas tém sido substituido pela consideração de que os estágios mais avançados da vida são momentos propicios para novas conquistas, gaiadas pela busca do prazer e da satisfação pessoal. As experiências vividas e os saberes acumulados são ganhos que oferecem oportunidades de realizar projetos abandonados en outras etapas e estabelecer relações mais proficuas com o mundo dos mais jovens e dos mais velhos". (Debert, 1999, p.14).

Além de uma revisão nos estereótipos e mitos relacionados à velhice, o próprio velho precisa assumir estas novas significaçōes, decidindo, participando e construindo novas relações sociais. Neste sentido, Dias (1997) nos coloca que:

"O novo paradigma de velhice também passa por decisões que os velhos deverão ajudar a tomar com relação ao dia-a-dia da comunidade, deixando de lado a visão e as palavras de que isto é coisa para os mais jovens".... (p.39)

No universo teórico que está surgindo na contemporaneidade, onde o conceito 
de velho/velhice está se redimensionando surgem dia a dia proposiçôes teóricas. que constituem verdades provisórias sobre a temática. Em uma sociedade com estilo unietário, juventude e velhice são valores e não mais um recorte etário. Além disso. Andrade (1999) alerta sobre a urgência de superação da fragmentação da vida da pessoa em fases/etapas separadas, bem como a implicação, diante do reconhecimento desta realidade, de uma formação permanente. Tal assertiva nos remete ao objetivo de reflexão do presente estudo.

"A sociedade toda deve, também tomar consciência da urgente necessidade de superar a fragmentação da vida da pessoa à etapas claramente separadas, com uma conseqüiente perda da sua unidade, una fragmentação ligada ao arco evolutivo-involutivoda existência

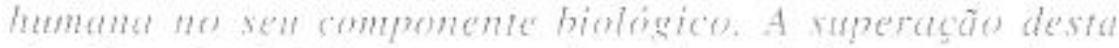

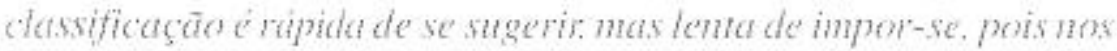
leva à questâo da "formação permanente". (Andrade, 1999. 12.87 ).

Moody apud Debert. 1999. p. 19) atraves do uso da expressăo "curso de vida pós-moderno" aponta para um apagamento dos comportamentos tidos como adequados às diferentes categorias de idade. Held apud Debert $(1999$, p.19) coloca que a "descronologizaçâo da vida" se caracteriza como uma experiência contemporânea.

"O carso da vida como construção social e cultural não pode ser entendido como algo que os seres humanos podem fazer e refazer; um processo que näo impōe limites à criatividade e ao qual qualquer sentido pode ser atribuído. É preciso ol har, com mais atençäo, para os limites que a sociedade coloca à nossa capacidade de inscrever a cultura na nature:a". (Debert, 1999, p.67).

Nesta perspectiva, ser jovem ou ser velho não caracteriza uma fase etária, mas sim um valor. Novas significações começam a ganhar espaço em nossa sociedade e a desmistificação de preconceitos e mitos são foco de interesse interdisiciplinar.

"... a juventude perde conexão com um grupo etario especiffico, deixa de ser um estágio na vida para se transformar em valor, um bem a ser conquistado em qualquer idade, através da adoção de estilos de vida e formas de consumo adequadas". (Debert, 1999, p.21).

As transformações e dinâmica da rede social provocam e estabelecem a necessidade de mudanças no pensamento, dito erudito. Assim, o termo "curso de vida" 
aparece figurando neste cenário, como uma nova compreensão a ser pensada. refletida. questionada no meio da gerontologia. Debert ( 1999) complementa sobre o termo no trechoabaixo.

"O carso de vida transforma-se' em am espargo de experiências abertas e não de passagens. ritualisadas de uma etapa para outra. Cada fase de transição tende a ser interpretada, pelo individuo, conno uma crise de identidade e o carso de vida são construádos em termos da necessidade antecipada de confrontar e resolver essas fases de crise.(...) Curso da vida pós-moderno' é uma expressão cunhada por Moody (1993) para dar conta das mudanças que

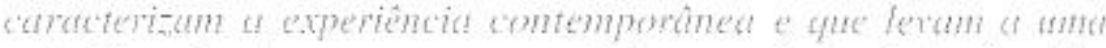
relariviasano das nomas apropriadas a cada estagio da vida. indicando a emergencia de ama sociedade en que a idade passa at ser imelesante". (Debert. 1999. p.53-56).

Precisamos levar em conta muitos aspectos referentes ao diálogo velhice versus sociedade, são eles; o que os teóricos fomentam sobre o assunto: o que os idosos pensam. e como a sociedade reage a estes novos signos. E oque é mais importante: as transformaçōes decorrentes deste fenômeno transformado em problema social - o da velhice. 
Educação Física e Velhice - refletindo seus caminhos

Dà Educaç̣̄õo dà inconclusão humana

"Gosto de ser gente porque a Historia em que me faço com os sutros e de cuja feitura tomo parte à un tempo de possibilidadese näo de determinismo". (Paulo Freire)

Primeiramente, gostaria de expor a compreensão de Educação, conceito a ser mediatizado e dialogado com os envolvidos: educador-educando e educando-educador, como retere-se Paulo Freire. Entendo at Educuçãoenquanto açüo de desenvolvimento do homem. E. portanto. um tenomeno de desenvolvimento pessoal que só possivel através do relacionamento interpessoal e do contato mediado com o un mundo dat vida. Através da educuçào. o "eu" e o "outro". mediado por um processo djalogico. constroem at sociedade.

"Em oposiçāo ao processo expontâneo e natural da interaçăo humana no meio social, a educaşäo se fas açäo proposital de am grapo humano sobre si mesmo é sobre sua continuidade atratés de novas zeraçồes". (Marques, 1996, p. 50).

Neste universo que aparece muitas vezes polarizado, por mais que entendamos que estes pólos devem ser desmistificados, o diálogo torna-se elemento fundamental do processo educativo, elo que estabelece a interdependência necessária, obedecendo a uma interlocução de saberes evidenciada por Marques ( 1996) que nos diz que:

"... a educação se cumpre num diálogo de saberes, nâo em simples troca de informações, nem em mero assentimento acrítico a proposições alheias, mas na busca do entendimento compartilhado entre todos os que participem de mesma comunidade e de vida, de trabalho, de una connunidade discursiva de argumentação. Interlocução que se faça de saberes não apenas prévios. os saberes de cada um, sobretudo na participação de cada um e de todos na reconstruçäo de que resultem novos saberes, os saberes de cada especifica comunidade en cada diversa situação". (p.14)

Em uma outra linguagem que demonstra ser esforço na mesma direção, a proposta 
de educação dialógica de Freire (1987) critica a educação que chama de "bancária" e enfatiza sobre a busca dos saberes. busca que se dá a partir do diálogo mediatizado com o mundo, justificada na afirmativa de que "ninguém educa ninguém, ninguém educa a si mesmo, os homens se educamentre si, mediatizados pelo mundo" (p.68). Ainda resgatando o caráter de buscà e invenção-reinvenção, o mesmo autor enfatiza:

"So existe saber na invençào, reinvençăo, na busca inquieta. impaciente, permanente, que os homens fascm no mundo, com o mundo e com os outros. Busca esperançosa também". (p.58)

Esta busca se dá entre os saberes dualizados constituídos pelos do Educador e os do Educando os dar Ciẻncia eos do Senso Comum. os da Doxa es da Alétheià os do cotidiano es da elite acadèmica. Estes pólos contraditórios constituem uma indağą̧âo que deve ser superada em nome da unidude destes saberes. uma vez que a idéia dicotomizada de dojs pólos sugere a aniquilaç̃o e/ou negacão de um deles. o que no meu entendimento seria retroceder na discussấfconstruçuo dos saberes. Na busca por camintaos de uma Educação/ Educação Física a partir da construção/reconstrução de saberes, esta discussão torna-se pertinente por permear as concepçōes norteadoras presentes nesta reflexão traduzida em dissertação de mestrado. Estas premissas de rede complexas de compreensōes e concepçōes confundem-se com a característica fundamental da prática/ práxis que utopicamente perseguimos.

Além da interlocução dos saberes, como requisito para a construção e reconstrução de novos saberes, e da proposta de Educação Dialógica, busco o entendimento de Furter( 1987) onde considera que, se penso um homem em constante desenvolvimento, uma construção contínua, obviamente deve considerar a existência de uma educação que ele denominou de permanente.

Consideramos a perspectiva de educação que considera que o processo de apreensão de conhecimentos é constante e contínuo na existência. De acordo com FURTER (1987) ela pressupõe um homem inacabado, sempre em busca de seu acabamento.

Freire (1998) também se refere ao inacabamento do ser humano como próprio da experiência vital. O ser humano é cultural, histórico, inacabado e consciente de seu inacabamento.

"Minha franquia ante os outros e o mundo mesmo é a maneira mais radical como me experimento enquanto ser cultural, histórico, inacabado e consciente do inacabamento. (...) $\mathrm{Na}$ verdade, o inacabamento do ser ou sua inconclusão é próprio da experiência vital. Onde há vida, há incabamento. Mas só entre mulheres e homens o inacabamento se tornou consciente". (FREIRE, 1998, p. 55) 
Esta perspectiva de inacabamento nos remete ao entendimento de que a educação, não pode ser dissociada de sua característica de ação humanizante contínuá. Freire (1987, p.72-73) nos coloca que:

"O homen conno un ser inconcluso, consciente de sua inconclusão, exeu permanesnte morimento de basca de ser mais. (...) Na verdade. diferentemente dos outros animais, que sāo apenas inacabados, mas nāo sāo históricos. os homens se sabem inacabados. Tèm consciência de sua inconclusão. Ai se encontram as raizes da educação mesmo, como manifestaçäo exclusivamente humana. (...) Dai que seja a educaçāe un quefazer permanente. Permanente, na

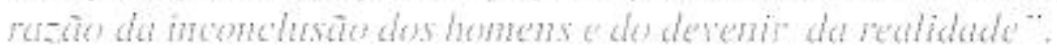

A consciência de inconclusão do homem nos remete à responsabilidade de responder as demandas sociais considerando esta dimensäo. Portanto. nào podemos udmitir que nostos projetos educacionais e pedagogicos se fimitem ato espaço institucional de ensino. ou seja. escolas, universidades.... eles. os nossos projetos. devem sim transcender e emergir no conteúdo histórico e social. o que implica a não diferenciação de classes etárias, incluindo assim, a velhice e o idoso como sujeitos e objetos de estudo, ná busca desta unidade por hora paradoxal. da ação educacional, na condição humana que confere característicá social, cultural e histórica diferenciada dos animais.

Além do que os autores já citados enfatizaram acerca da temáticá, devemos destacar o que Both. Portella\&Both(1994). Both(1993) E Both (1999) denominam de "gerontogogia". Para o autor, gerontogogia é a ciência cujo objeto de investigação e ação reside no processo de desenvolvimento humano tardio e em suas implicaçōes educacionais em todas as faixas etárias e em todas as instituiçōes nele envolvidas. (Both, 1999, p.32)

O mesmo autor acrescenta os objetivos da chamada "gerontogogia" e sua significação quando estabelecida de fato. Para isso destacamos o trecho abaixo.

"A gerontogogia, como educação voltada para a produção de significados no desenvolvimento tardio, torna densa sua razäo de ser porque constrói um conjunto de representaçōes sobre o potencial de desenvolvimento tardio e realiza esforços para definir papéis significativos para o exercicio da sociabilidade dos mais velhos".(Both, 1999, p.32)

A pedagogia para idosos, em primeiro lugar é algo novo, portanto questionável; em segundo lugar, aprender é possível em qualquer idade, inclusive na velhice; em terceiro 
lugar, a pedagogia não resolve o problema da velhice. mas pode ajuda-la a viver melhor: Além disso, uma pedagogia voltada aos mais velhos deve partir dos interesses, dos desejos e levar em consideração o seu contexto social, sua história de vida. (Rodrigues. 1993).

Até então. comentamos sobre a compreensāo de Educação na relação direta com a velhice, bem como a visão de homem, considerada neste estudo a partir das características de inacabamento e inconclusão, cientes da inserção em uma sociedade igualmente inconclusa. Neste momento, com o intuito de encaminharmos a reflexāo pară o campo especifico da Educaçāo Física. precisamos resgatar elementos da história de sua prática e intervenção no Brasil, a fim de a partir destes saberes primeiros, culturais e históricos, contribuir para a continuidade da caminhada na construção aqui proposta.

Das subordinações históricas da Educação Física

De acordo com Soares (1996). a Educaçõo Física como concebemos atualmente têm suas raizes na história da Europa de fins do século XVIIl e inicio do século XIX e moditicoul-se através dos tempos.

Portanto, contextualizando a Educução Físicu brasilenar. precisamos distinguir dois momentos que Bracht ( 1992) como: ato momento em que a Educaçăo Física estava subordinada aos códigos da instituiçāo militar no contex to das décadas de 30 e 40 e: b-o momento em que a Educação Física estava (está) subordinada aos códigos da instituição esportiva a partir dos anos 50 .

Este contexto de subordinações retrata uma situação paradoxal, sendo a busca de uma identidade e da legitimidade uma preocupaçūo entre os profissionais da área na atualidade.

\begin{abstract}
"A Educação Fisica brasileira, historicamente, tem vivido uma situação paradoxal. Por um lado, tanto terminológica quanto legalmente vincula-se à instituição educacional; por outro, suas ações no interior do espaço escolar foram, tradicionalmente. constituidas segundo orientaçōes estranhas a este meio, advindas sobretudo das instituiçōes militar e esportiva, de tal forma que a Educação Física (EF) não pode elou nem precisou desenvolver um corpo próprio de conhecimentos. E. sem esse, tornou-se presa fácil para aquelas instituiçōes que a instrumentalizaram como correia de transmissão ao meio escolar, de acordo com interesses sociais de classes hegemônicos". (Ferreira, 1995, p. 193).
\end{abstract}

Os objetivos, conteúdos, modo de transmissão e avaliação, entre outros aspectos 
cumprem funçōes sócio-pedagógicas que dizem respeito do momento histórico pelo qual nos estamos passando. Até então, esta lacuna era preenchida pelas duas subordinaçōes já citadias nos parágrafos anteriores, e agora? Qual o corpo de conhecimento que nos garantiria identidade e legitimidade?

Principalmente nos anos 80. profissionaise estudiosos da área buscaram saídas para esta indagação. sendo que podemos destacar os téricos com base $\mathrm{em}$ um referencial marxista, exercendo o papel de questionar. criticar. porém não apontaram nenhuma proposta prática de intervençāo. Além deste movimento, nasceu fora do páis uma proposta de Educação Física, a Psicomotricidade, que veio suprir as necessidades instrumentais da Educação Física de primeira à quarta série, representando um método alternativo. porém sem caráter de questionamento ou crítica.

Na última décuda. a Educação Físicu brasileira vem passando por transformaçôes importantes. Apesar dos avanços nesta áreat. no sentido de crítica às concepçoes e propostas de Educação Fisica vigentes, nos ressentimos de propostas criticas que nos apontem "saidas" concretas para a intervencão educacional. Portanto. precisamos urgentemente relletir acerca du concepça de ensino, de conteudo e de método com o intuito de melhoria em nossa prática pedagógica.

Nesta caminhada podemos destacar algumas obras que propōem novos caminhos práticos para a Educaçāo Física: "Visāo Didática da Educação Física. Análise Crítica e Exemplos de aula", livro de um grupo de trabalho da UFSM e da UFPE: "Metodologia do Ensino da Educação Física". livro de um coletivo de autores: "Transformação DidáticoPedagógica do Esporte", livro do professor Elenor Kunz: "Didática da Educaçāo Físical", de um coletivo de autores, com organização de Elenor Kunz.

Todas estas obras marcam um momento histórico especial em nosso país e caminham para propostas de Educação Física Escolar. Podemos afirmar que a instituição escolar centraliza as atençōes dos teóricos que pensam e veiculam o conhecimento na área de Educação Física na atualidade. Consideramos esta situação problemática, uma vez que não reflete a identidade da Educação Física, pois sabemos que ela não se limita aos muros das escolas, sendo, pois, possui um compromisso social com as demais instâncias na sociedade. Nossos profissionais encontram-se em clubes, escolinhas, academias, centros de convivência para terceira idade, hotéis, clínicas e tantos outros espaços de atuação profissional. Naárea técnica, ou seja, onde estão incluídos manuais de exercícios ginásticos, treinamento de alto nível, etc, pode encontrar literatura pertinente. Porém, acreditando que a Educação Física não se limita a uma dimensão técnica de movimento propriamente dita, e também, por acreditar em seu caráter educacional entendendo como fundamental discutirmos a identidade da Educação Física em nossa sociedade.

De acordo com Santin (1992), "a educação física existente possui um perfil deficiente, parcial, serviçal e instrumental". Neste sentido deveríamos nos perguntar sobre

\footnotetext{
KINESIS, SANTA MARIA, $N^{\circ} 25,2001$
} 
as funções de sua prática. com o intuito de construirmos sua identidade (fica a discussão de ela existe, não existe, ou precisa ser revista).

A Educação Física a ser "inventada" como Santin (1992) propōe "terá a tarefa de garantir o equilíbrio do ser humano em sua vida planetária. Esta não é uma tarefá que se executa num determinado momento apenas, mas precisa acompanhar o homem ao longo de toda a sua existência". Partilhamos deste entendimento percebemos que a discussão de Educação Física não pode mais se restringir em sua dimensão escolar. Urge então a necessidade de pensarmos uma Educaçōo Física que poderia ser chamada de "permanente".

\section{Da Educação Física também na velhice}

Encontramos apoio de referencial teórico para o trabalho da Educação Física na velhice nas áreas "mães". comocostumam ser denominadas, da biologia. sociologiae psicologia. Além destas a gerontologia vêm suprit a lacuna de conhecimentos necessários para respaidar nossas intervençóes. Este quadro nos aponta. que a Educação Fisica na vethice tambem. bem como a Educaça Fisica escolar se ressente da falta de una identidade própria. e/ou um corpo teórico próprio. o que e perseguido nas discussôes que buscam fundamentar a ciêncià e/ou ciências do Movimento Humano,

As iniciativas de Educaçāo Física para terceira idade estāo disseminadas em todo país integrando programas de universidades, secretarias estaduais e municipais, SESC, SESI. academias de ginástica particulares. clubes, entre outros. A cada dia a adesão para a prática saudável de atividades físicas na idade avançada aumenta e o compromisso social também, decorrentes do envelhecimento populacional acarretado pelo avanço demográfico.

Nos encontramos, enquanto profissionais de Educação Física, por um lado em crise de identidade e de especificidade, com encaminhamentos das discussōese propostas voltadas quase que fundamentalmente para a escola, e por outro com o mercado informal de academias, personal training, escolinhas em crescente aceitação. As subordinações histórico-sociais encontram-se em todos os segmentos, ditando os conteúdos e objetivos da Educação Física em todas as áreas de atuação, e a terceira idade, idade feliz, melhor idade, maturidade, entre tantas outras denominaçōes também obedecem a estas subordinações.

Qualidade de vida é a expressão mais veiculada em todas áreas como objetivoe meta das mais diferentes ações. Aspectos técnicos da atividade física e a prevençāo de doenças através do exercício físico vêm sendo o foco principal de estudos. Acredito que estes conhecimentos sāo fundamentais, porém insuficientes, por privilegiarem apenas a competência técnica e objetiva do movimento. 
"Cada ves mais estudos vên evidenciando a atividade física como recarso importante para minimisar a degeneraçăo provocada pelo envelhecimento, possibilitando ao idoso manter uma qualidade de vida ariva. Visto que ela tem potencial para extimular värias funçöes essenciais do organismo. mostra-se näo so um coadjuvante importante no trakamente e controle de deenças cronicodegenerativas (como diabetes. hipertensäo, osteoporose). mas é tantbém essencial na manutençāo das funçöes do aparelho locomotor: principal responsável pelo desempenho das atividades da vida diaria é pelo grau de independência e autonomia do idoso". (Okuma. 1998, p. 5/)

Sabedores dos benefícios da atividade fisica na velhice. devemos pensar que proposas mais amplas devem ser pensadas, no sentido de uma pedagogia revisada. Uma pedagogia que considere outros aspectos que não somente os fisiológicos mas também dimensoes socidis e psicologicas tratadas em suacomplexidade de redaçōes. principadmente nos seus conceitos de inacabamento do homem e historicidade e culturu do mundo/ sociedade. e, portanto voltada para o homem em todas as faixas etárias, em todas as suas dimensões. Acredito que os estudos devam caminhar para propostas pedagógicas. Somente através de açōes educativas alcançaremos a consciência e o significado da tão almejada qualidade de vida.

Perceber que a Educaçāo Físicat tem o caráter educacional e pensar propostas para idosos nesta perspectiva compromete a ampliar as propostas atuais e projetar um projeto pedagógico. O trabalho citado acima é uma iniciativa entre tantas que estão construindo este novo fenomeno. Acredito que precisamos ousar mais, pensar uma pedagogia que inclua o processo de envelhecimento como interveniente em seu projeto. uma pedagogia que pense o homem em toda a sua existência.

Em uma situação mais específica. almejo que as discussões epistemológicas, pedagógicas, filosóficas, sociais sobre a Educação Física, incluam em seu panorama reflexivo as questōes referentes ao envelhecimento humano, pois assim evitaria o processo de criação de uma pedagogia especial, excludente, por entender o idoso como um ser "diferente", desprovido do que é humano, necessitando assim, de propostas "diferentes".

Consideramos que a compreensão de movimento humano na velhice sendo uma técnica para desenvolver o físico, prevenção de doenças e objetivar terapêutica insuficiente e dicotomizada, constituindo uma realidade a ser desmistificada. Compreendemos o movimento humano como uma possibilidade educacional, sem deixar de reconhecer os valores fisiológicos do exercício, considerando indissociáveis tais valores ou aspectos. Falo da compreensão de movimento, enquanto cultura corporal/ou de movimento para 
terceira idade nestes termos, porque até entâo muito se tem justificado sua prática pelos seus benefícios á saúde, e muito pouco se tem discutido que tal prática pode configurar um elemento pedagógico de desenvolvimento global na velhice.

Devemos nos apoiar em um paradigma da reflexão fenomenológica do movimento e. por conseguinte, em uma visão pedagógica de Educação Física, corpo e movimento, conforme discorreremos no próximo capitulo. Através de nossa práxis na Educação Física. transcender o cotidiano escolar e surpreender o cotidiano de todas as pessoas, em todas as suas idades. A demanda social é esta, o movimento não pode ser algo dado, acabado a ser recebido exclusivamente durante a vida escolar, ele deve sim ser despertado como dimensão significativa que acompanham o sujeito durante sua existência. um meio de comunicação e de desenvolvimento de competências e da construção e manutenção da autonomiar. Portanto. não nos conformamos com a exclusão das outras faixas etárias. entre elas a terceira idade, nas discussōes das propostas de Educaçāo Fisica em ebuliçāo atualmente em nosso pais. Assin. caminharjamos rumo a uma compreensäo continuada. ou ainda permanente de nossas intervencioes.

\section{Fundamentando uma Educação Física Permanente}

\section{Compreensões de corpo e movimento}

De acordo com Trebels (1983), há uma diferença fundamental entre um "Se movimentar" e um simplesmente, "ser movimentado". O autor cita estudos nos quais esta diferenciação é abordada, W. Ennembach. "Imagens e co-movimentos" (Bild und Mitbewegung, 1989), baseados nos resultados experimentais de Held. conclui que é necessário compreender diferentemente tais conceitos nas pesquisas do Movimento Humano.

"A diferença entre os dois conceitos de movimento pode. a partir do arranjo experimental de Held, ser aclarado (...). O sujeito experimental que empurra a cadeira de rodas, se movimenta por si mesmo e configura com isto, para si, una relação com o meio circundante, o qual só se torna percebivel a partir desta relação. $O$ sujeito experimental passivo, ao contrário, por ser empurrado na cadeira de rodas, é movimentado. O sujeito de seu se-movimentar não é ele mesmo, mas sim o sujeito experimental ativo, que o empurra na cadeira. Este último aprende a se orientar no ambiente. o outro não". (Ennenbach apud Trebels, 1983) 
Trebels ( 1983 ) cita Buytendijk com seu livro "Teoria Geral da Conduta e do Movimento Humano" de 1956 observa os seguintes pontos de referência do movimento humano enquanto movimento próprio: movimentoé uma açăo de um sujeito: movimentoé unna ação vinculada a uma determinada situação, e: movimento é uma ação relacionada a um significado.

O primeiro ponto a ser considerado é que o movimentar-se "sempre é ação, é atividade de um ator de movimento que produz o movimento concreto, que é portanto o autor do comportamento de movimento". Desta forma ser movimentado passivamente e movimentar-se como movimento próprio possui diferença significativa. Por exemplo, uma aula onde os idosos somente reproduzem os movimentos de uma rotina de exercícios a um determinado ritmo e intensidade pré-determinada não têm sentido e significado quando comparada a uma proposta de movimentar-se a partir de um estímulo mesical ou de um temia. onde cada individuo exerce sua corporeidade. conforme Merleau Ponty, o homem enquanto ser-no-mundo.

O segundo jonto evidencia que o movimentar-se "acontece sempre numa sifuaço concreta, que esta estruturada em si mesma". E neceswirio levar em conta o contexto situacional. Quando, por exemplo, trabalhamos atjvidades com bolas com os idosos eles precisam apreender determinadas estruturas, o espaço onde se encontram - quadra poliesportiva. salāo, ochāo de madeira, cimento, ou ainda tapete: a bola seu peso, tamanho. material que é confeccionada, etc. O ato de quicar, agarrar ou lançar a bola por si só não é açūo do corpo do movimento. O manuseio do material é uma atividade baseada em uma certa situação que é estruturada e depende diretamente do contexto situacional.

O terceiro e último ponto a ser considerado refere-se ao movimentar-se como uma atividade relacionada ao sentido. "movimentando-se, as pessoas sempre seguem certos sentidos de movimento, que sāo descobertos e. de maneira específica. desdobrados pela ação". A fenomenologia coloca como orientação intencional. A relação do material com o sujeito deve descrever uma estrutura dialógica, formando uma unidade no comportamento de movimento vislumbrando-se assim uma atividade relacionada ao sentido.

Esta situação passa pela distinção de dois paradigmas na teoria de movimento humano apresentados por Buytendijk apud Trebels (1992, p.338-344): 1-o paradigma das ciências naturais; 2-o paradigma da reflexão fenomenológica do movimento.

A partir destes dois paradigmas, Hildebrandt (1993) aponta duas visões: A visão científica natural do movimento - uma visão considerada pelo autor de antipedagógica e a viš̃o fenomenológica do movimento, esta considerada como uma visão pedagógica.

Segundo o autor, a primeira visão reduz o movimento à sua perspectiva científica natural apreensível. A individualidade de cada um como pessoa não existe. A concepção de corpo é substancial, como foi colocado no capítulo sobre as compreensōes de corpo 
e movimento, neste estudo. O mundo do espaçoe dos aparelhos é objetivado fisicamente e osentido de movimento, conforme significado configurado pelos homens, nãoé discutido. Oensino se dá a partir de um monólogo controlado pelo professor.

Sobre a segunda visão de movimento, que constitui uma concepção contráría da primeira, o autor coloca que nāo podemos observar movimentos, mas sim. homens se movimentando. A concepção de corpoé relacional, conforme será comentado no próximo capítulo deste estudo. O movimentoé um diálogo entre o homeme o mundo: cada homem conversa com seu mundo, e a língua é o movimento. O homem coloca perguntas de movimento para seu mundo se movimentando e recebe respostas de movimento. O mundo não é só físico, são também os outros homens, sendo que o homem entra em contato com o meio e os outros homens pelo movimento.

Das duas visões de movimento colocudas que correspondem aos dois paradigmas comentados a segunda visāo é aquela que corresponde ao que almejamos em temos de proposta de Educação Física. pois só ela legitima o caráter pedagógico perseguido. só ela permite a disputa subjetiva com o mundo. séla desencadeia o diálogoque constrói o ser:

"Devenos ampliar esta reflexão do movinento enquanto "diälogo entre Honeme Mundo", ou seja. ampliar a concepção de Se movimentar enquanto acontecimento fenomenológico relacional. ou melhor, como uma relação intencional de ações significativas. Esta concepção que deve servir de base para a interpretação pedagógica que se pretende fazer do Movimento Humano. ou seja. estudar o movimento para orientar e fundamentar um trabalho de intencionalidade pedagógica emancipatória para a Educação Fisica Escolar". (Kun-. 1994, p. 74)

O conceito do movimentar-se humano que se contrapõem ao conceito de movimento no sentido de ser movimentado passivamente, nos remete à reflexão acerca do contexto situacional e a maneira como conduzimos o ensino da Educação Física atualmente. Que concepções norteiam nossa prática/práxis? Como ensinar o aprender o movimento?

Os três pontos destacados por Buytendịk sāo ligados uns aos outros na concepção dialógica de movimento de Gordijn:

"Na concepção dialógica de movimento, o ator do movimento (a criança, o adolescente, o adulto), a situação de movimento e o sentido de movimento, que se manifesta na ação de movimento, são ligados uns aos outros, sendo descritos e analisados na sua 
ligaçāo. Trata-se da relação básica do homem com o mundo. é do seu mosinentar-se, que deixa compreender sentidos e possibilita ao mesmo tempo segui-los. Morinentar-se é am comportamento do homem numa "relaçäo pessoal-sifuacional". (Trebels. 1992)

Esta concepção vai alén de contribuir para a compreensĩo do movimento humano e também permite conclusões pedagógico-didáticas. tornando-se significativas e orientadoras na relaçāo entre aprender e ensinar a movimentar-se.

Conforme Gordijn apud Trebels (1998) o movimento desenvolvidoe condicionado pelo diálogo se cria no conjunto de "sentido objetivos e subjetivos de movimentos". "Pelo diálogo de movimento nasce o mundo como meu mundo de movimento no ser-assim, ele ganba para minn uma estrutura específica".

De acordo com Hildebrandt 199310 movimentar-se so é uma forma da disputa do homen com seu mundo. do qual ele recebe os significados. O autor cita Gordijn que coloca mais duas formas: pensare falar. Exemplifica com o segunnte: "é possivel observarse uma prscina e pensar sobre ela. Também é possivel falar algo sobre a piscma. Mas também é possivel jogar-se na água .Assim. o homem vive em diferentes mundos de significados que são cada vez mais determinados pela forma de acesso que ele pode escolher. Outro exemplo: uma cadeira pode significar um banco de descanso para quem fez uma longa cuminhada, mas também pode significar um meio de subir para alcançar ou abrir uma porta de um armário.

"O problema das "Visões de homen" a partir do ponto de vista de concepções de Movimento, culmina para Tamboer na questäo da "Concepção de Corpo", ou seja: "o corpo enquanto prisão da Alma". "o corpo enquanto aparelho ou instramento", o "corpo enquanto máquina", o "corpo enquanto instrumento do espirito". o "corpo enquanto sistema de processamento de informaçōes", o "corpo enquanto objeto físico". Com tais interpretaçóes da "concepçāo de corpo" no sentido metafórico, articulam-se simultaneamente, aqui especialmente modelos dualisticosconcepçôes de Ser Humano". (Trebels, 1992 p..34l)

Tamboer, apud Trebels (1992) desenvolveu uma espécie de "tipologia das concepções de corpo" que pretende discutir as concepções de corpo. Ele sugere dois níveis de conceitos relativos ao corpo: "concepção de corpo substancial" e "concepção de corpo relacional".

Corpo substancial é uma concepção entendida por Tamboer onde o corpo é uma 
entidade, unidade isolável. Nesta concepção o corpo caracteriza-se por uma massa que se desloca através do tempo e do espaço. O corpo assim entendido pode tornar-se objeto de investigaçōes empíricas baseadas no paradigma empírico analítico, já que ele pode ser observado, descrito e medido sem maiores complicações.

Trehels (1998) aponta metáforas de uma imagem substancial de corpo como sendo: "caircere. engrenagem, máquinà at vapor. sistema de processimento de informaçōes. etc".

Diferenciando-se da concepçũo de corpo anterior. Tamboer propōe o corpo relacional, baseadas nas posições filosóficas da fenomenologia, em especial, em MerleauPonty (1999). Esta concepção pressupõe alguns conceitos considerados referenciais que são a "unidade primordial" de homem e mundoe, a interpretação existencial de homem. enquanto um "ser-mo-mundo" e. finalmente. u convicçāo de que a corporeidade éo "modo do nosso ser-no-mundo". Assim. o corpo relacionat-se intencionalmente ou ainda se trata de uma "compreensĩo-de-mundo-pela-ação".

Contudo precisamos estar cientes que as duas concepçoes de corpo: a substancial

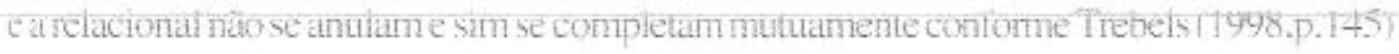
nos coloca:

"A imagem relacional do corpo e a imagem substancial do corpo näo devem, cada uma, ser colocadas de forma absoluta, elas se completam e, neste sentido, estão interligadas una com a outra. Pois- mesmo que de forma diversa-em ambas se desenvolve a estrutura básica relacional comum. (...) Por isso, nāo há razāo para pressupor un abismo irreconciliável entre relaçōes causais e relações de sentido. O que o corpo humano é, só pode ser reconhecivel en forma de imagens. Suas variantes substanciais e relacionais organizan uma realidade, na qual, em última instância. näo se mostram claras linhas limítrofes".

A implicação teórica vista até então pode nos remeter a seguinte reflexão que diz respeito aos indivíduos mais velhos: a partir da perspectiva do observável, do medido, do físico, do que foi chamado de corpo substancial, podemos observar que o corpo envelhecido naturalmente tem a velocidade, a força dos movimentos diminuídos. obedecendo a uma curva descendente. Portanto, dentro de uma imagem substancial de corpo perpetua-se preconceituosamente uma imagem negativa do envelhecimento. Buscamos, portanto compreender o corpo e o movimento baseado em um paradigma fenomenológico, onde o corpo é o modo de ser e estar no mundo, onde o diálogo é o que desencadeia os processos de ensinar e de aprender, em todas as fases da existência, 
indistintamente.

A discussão das concepçōes de corpo e de movimento deve nos auxiliar na busca de orientaçôes pedagógicas que norteiem a construção do ensinar a aprender, em busca de uma Pedagogia crítico-social e que contribua de maneira efetiva na vida das pessoas em todas as idades.

\section{Competências para o bem viver}

Escolhemos o termo competência para figurar entre os elementos que fundaunentariam uma Educação Física permanente, por considerarmos que somente teremos condições de desenvolvimento, liberdade, autonomia de ação e emancipação se, através de um processo pedagógico que nos tome competentes pura tal.

A tão comentada qualidade de vida. somente pode ser alcançada a partir de competências de hem viver. isto é. só possivel qualidade quando se tem competéncia. Entäo. qualidade de vida representaria uma aproximaçấo de elementos que signitiquem competencia de bem wiver.

De acordo com Kunz (1994) que baseou seus estudos em Habermas. "a constituição de ensino pelas três categorias do Trabalho. Interaçào e Linguagem deve conduzir ao desenvolvimento da competência objetiva. social e comunicativa".(p.38)

"Para Maver (1987), extas três categorias formam a mediação de conteridos entre os ahunos enquanto sujeitos em desemolvimento c a realidade do mundo. O sujeito aprende e se desenvolve, mas também o mundo se transforma - omundo dos esportes, inclasive, de uma forma muito veloz - na medida em que passa a ser cada ves mais conhecido, preservado, dominado e destruido pelo homem".(Kun-.1994p. 37).

A competência objetiva refere-se aos conhecimentos e informações, destrezas e técnicas racionais e eficientes e o aprendizado de certas estratégias para o agir prático de forma competente. Esta competência está vinculada à qualificação das possibilidades individuais e coletivas permitindo um agir de forma bem sucedida no mundo do trabalho. nas atividades cotidianas e no tempo livre. Esta competência tem importância fundamental na vida dos idosos, pois é ela que proporciona a autonomia e a liberdade de movimento, de ir e vir, de autogestão.

A competência social está relacionada, especialmente com os conhecimentos e esclarecimentos que precisamos adquirir para entender as relações socioculturais do contexto em que vivemos. Os problemas e contradições destas relações, os diferentes 
papéis que os indivíduos assumem numa sociedade. Tal competência pode redimensionar a vida dos idosos, o questionamento dos papéis e preconceitos sociais relacionados ao envelhecimento, as limitações impostas pela sociedade e o envelhecimento social. a discriminação e a desvalorização da velhice constituem a desvalorização do homem.

A competência comunicativa permite que as interaçôes humanas tornem-se bem sucedidas e se estabeleçam. Nesta competência estão incluídas a linguagem verbal e a linguagem de movimento. Quando pensamos no desenvolvimento da competência educacional crítico-emancipatória. como Kunz ( 1994 ) idealizou e agora transfiro esta aspiração na construção de uma Educação Física para o homem, sem fronteiras de idade. a competência comunicativa tem papel decisivo: "Saber se comunicar e entender a comunicação dos outros é um processo reflexivoe desencadeia iniciativas do pensamento crítico". (p.39)

Mesmo sabendo da existência do "Mundo dos Sistemas". que invadiu e desconsiderou o mundo vivido. queremos entender que o nosso mundo é sempre um mundo vivido. que se vive. e sendo assim. o Movimento Humano não pode ser compreendido como simples reação a estimulos e em consequencia de torças e energias. Movinento que é Humano é sempre uma conduta para algo, como um voltar-se a algo para a sua compreensão, não pode ser jamais uma conduta por simples reação externa. Este movimento consiste sempre de uma totalidade de relações que envolvem situaçōes concretas e sentidos/significados para quem individual ou coletivamente o pratica. É neste sentido que Tamboer (1985) concordando com Gordijn, propõe que o movimento seja entendido como um 'Diálogo entre Homem e Mundo'. O Se-movimentar do Homem é sempre um acontecimento fenomenológico relacional, uma relação intencional de açōes significativas. O significado ou o sentido nessa relação dialógica é assim. constituído na relação Homem-Mundo e não pode se localizar somente no lado Sujeito. ou somente no Objeto, mas justamente na mediação de Sujeitos e Objetos de Homem e Mundo."(p.96)".

"Nossa subjetividade é assim, na idéia de Merleau-Ponty, objetivada na nossa maneira de 'habitar' o mundo, de trata-lo. de interpretá-lo e isto se manifesta en diferentes estilos, diferentes modos de agir e sentir: no caminhar: no vestir, no olhar, no falar; etc. E o mundo não é um 'mundo em si', mas é o mundo de todas as possibilidades do agir e perceber ou sentir: Ele é o nosso meio circundante. Subjetividade vai constituir-se assim, na 'nossa' forma de conhecer o mundo, onde ele se inclui, os objetos, a natureza, o outro e nós mesmos" (Kunz, 1994, p. 105).

Despertar as competências para os sujeitos viverem os seus mundos deve ser 
objetivo de um projeto de Educação Física. Perceber, falar, sentir e agir são verbos que se tornam realidade a partir do desenvolvimento do indivíduo. Este processo não pode ser separado dos aspectos culturais conforme o trecho abaixo.

"Manter o ser humano distante. ou afastado do real e do sensivel à sta caltura ao seu modo de agir. pensar e sentir é frapmentar sujeito e conhecimento, é evitar o conhecer reprimindo a curiosidade e a paixão pelo mando pelas coisas e pelo outro, é mantê-lo na ignorînciat". (Kun:. 1994, p.108)

Segundo Hildebrandt (1990). quando nos perguntamos sobre os objetivos de um desenvolvimento tazoável. por parte da educaçāo de como deveria ser configurado o processo da educaçào nas aulas de Educaçāo Física para garantir este desenvolvimento. as respostas destas nāo poden assumir uma neutralidade livre de valores.

Oparágrafo acima revela que oprotessor deve assumir seu ponto de vista deixundo tharo suas opçues pedagogicas. obectecendo a uma coerente relaço entre o discurso terrico e uprixis. Oautor coloca que as respostas dizem respeito a uma compreensão normativa da educaçấo de aula e de movimento, cujos critérios ele determina como sendo autonomia, liberdade e consciência crítica de açāo. Assim. uma rede de relaçōes deve ser considerada.

Até então abordamos as competências colocadas por Kunz (1994) na área da Educação Físicat. Por outro lado, Salvando as diferenças entre as duas abordagens, expomos o que sugere o antropólogo Featherstone apud Debert (1999, p.67), onde coloca que a sociedade exige de seus cidadãos três principais competências:

1- Habilidades Cognitivas - baseadas no uso da linguagem e na capacidade de comunicação, vitais para uma pesson tornar-se autônoma e aceita.

2- Controles do Corpo - a necessidade de controlar os movimentos do corpo, os movimentos dos nossos membros, rosto e cabeça, o grau de capacidades motoras que envolvem sentar, ficar de pé e andar, tanto quanto a capacidade de conter e reterfluidos corporais.

3- Controles Emocionais - a necessidade de controlar a expressão das emoçōes raiva, ira, inveja, ódio, choro, amor, desejo - de modo que explosões emocionais e perda de controle somente tomem lugar em ocasiōes e de forma que possam ser sancionadas e aceitáveis.(Debert, 1999, p.67). 
Mesmo conscientes das dilerenças entre o que os dois autores colocam em seus estudos, percebemos que as exigências sociais estão definidas e devem ser levadas em conta quando pensamos em propostas pedagógicas, no sentido de aproximaçāo das necessidades e dos objetivos de intervenção.

Buscamos através destes atutores respaldar a idéia de que estes elementos sâo importantes na construçāo/fundamentação de uma Educação Física Permanente por contigurarem exigencias e necessidades sociais da atualidade.

\section{Procedimentos metodológicos}

O objetivo deste estudo foi refletir acerca de uma açūo pedagógica visando umat Educaçāo Fisica Permanente. haseada nas signiticaçôes desveladas através dos depoimentos temáticos de vida dos idosos participantes dos projetos do NIEATI.

Em busca da especificidade da reflexấ foram traçados os seguintes ohjetivos especiticos identificar as compreensöes de movimento dos idosos entrevistados. resgatai as experiencias de novimento enquanto manifestaçòes da cultura corporal em fases anteriores de suas vidas; verificar as mudanças manifestadas a partir dá inserçāo dos idosos em atividades de Educação Física no NIEATI.

Utilizamos a metodologia da história oral temática. Os instrumentos de pesquisa foram: entrevista e caderno de campo, no qual foram registradas as observaçōes tanto do andamento do projeto como das entrevistas específicas.

A técnica utilizada foi a de análise de conteúdo, e para a análise das entrevistas foram feitos três cortes horizontais temporais que corresponderam respectivamente a: juventude, vida adulta e velhice.

\section{Convocando a comunidade argumentativa}

Com o intuito de estabelecermos o diálogo necessário a partir do resgate da "cultura de movimento" periodizamos o ciclo vital em três fases determinadas: juventude. vida adulta e velhice. O corte temático obedece aos objetivos específicos deste estudo, evidenciando a cultura de movimento.

A partir do corte temático, buscamos identificar as compreensōes de movimento das colaboradoras, resgatar experièncias de movimento e observar as mudanças através da participação do programa oferecido pelo NIEATI.

A história de vida de nossas colaboradoras constitui pano de fundo para a discussão das experiências de movimento que historicamente tem marcado a vida das pessoas. A importância destas informaçōes está na contribuição em uma proposta de Educação Física 


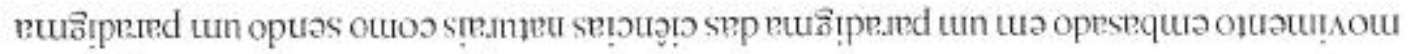

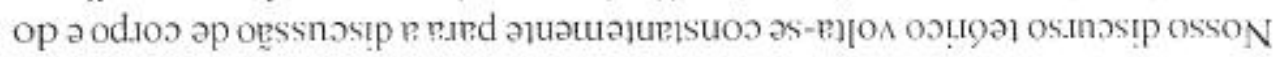

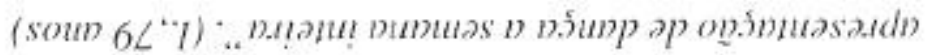

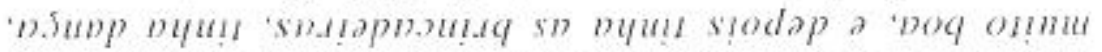

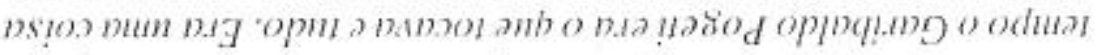

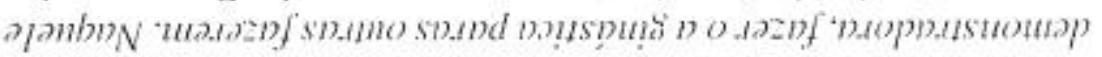

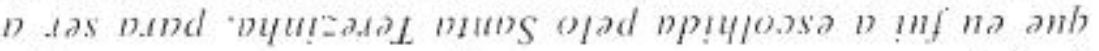

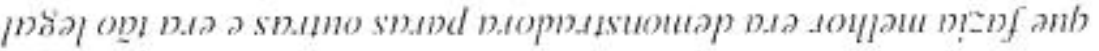

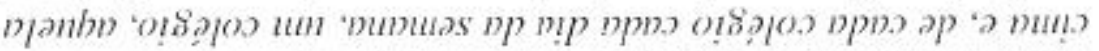

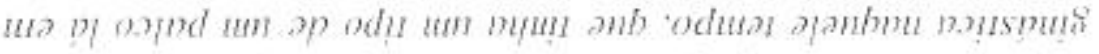

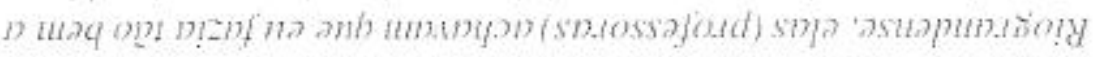

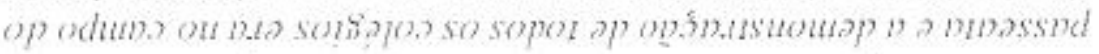

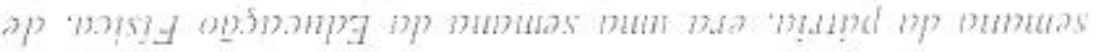

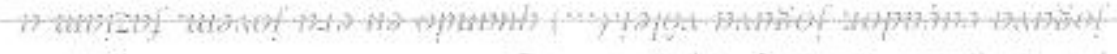

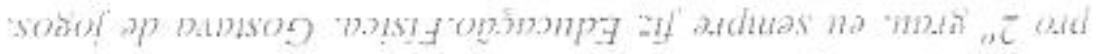

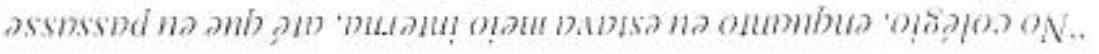

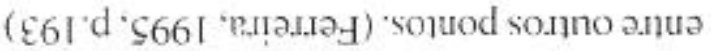

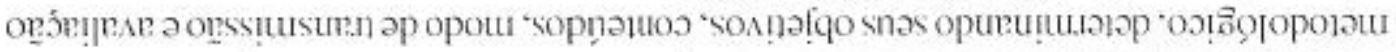

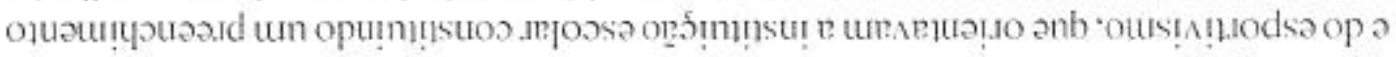

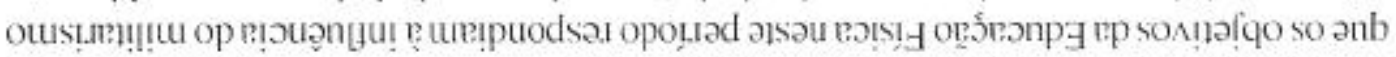
.muวuos sourpod 'tuọ.

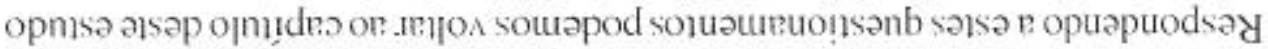

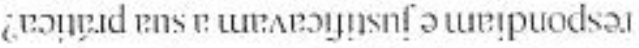

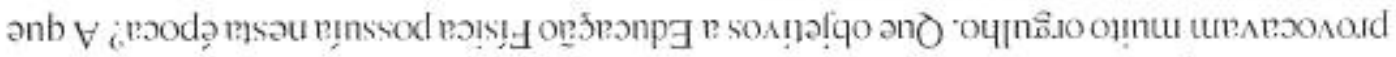

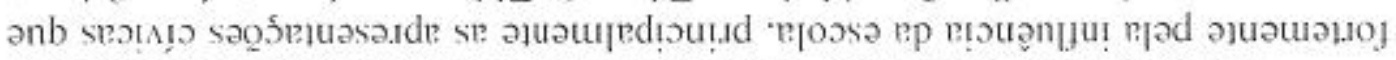

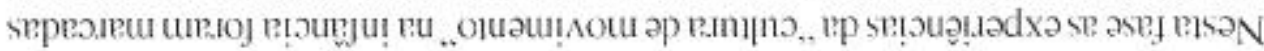

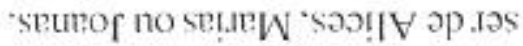

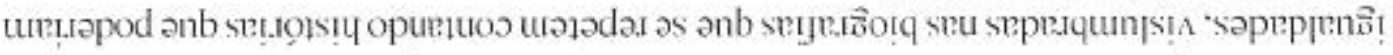

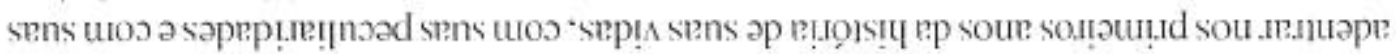

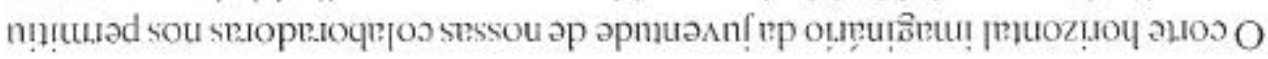

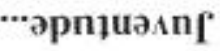

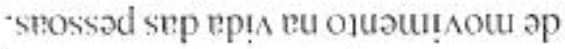

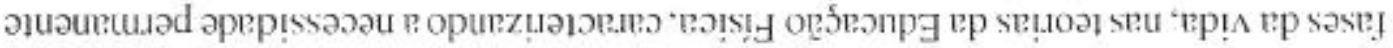

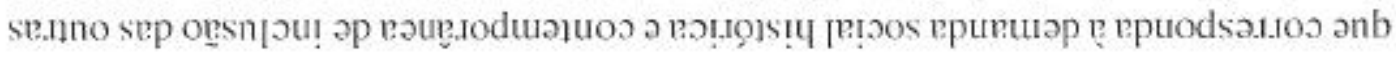


a ser transcendido, uma compreensão que deve ser refletida. Porém. como explicar o fato de que as colaboradoras, contam com prazer e incluem nas "boas lembranças" a imposição de movimentos e dos estímulos dirigidos pelo professor de Educação Física? Lembramos aqui do que Soares( 1996, p.6) coloca:

"Odesejo também é contstruíde socialmente...gesta-xe. en principio. do que se conhece. Rejeita-se, em principio, odesconthecides odificil. o elaborado,"

A inteligência dos alunos nầ é um vaso que se tem de encher; masé uma fogueira que é preciso manter acesa. Uma fogueira que não se extingue na tenra fase da vida, cla precia manter-se acesit durante a existencia. A escola neste contexto deveria ser un dos vértices que representariam o ponto de partida para as investidas de aprendizado eni outras fases do ciclo vital que näo somente aquelas em que estumos matriculados em una instituição de ensino.

Com a criação dos Sistemas Nacionais de Ensino. à ginástica foi o nome dado à Educaçũo Físicat sendo que observamos que as colaboradoras se referiam á prática de Educação Fisica, como "fazer ginástica ". A priori. a ginástica, em seus métodos e escolas não havia sido pensada para a escola, conforme Soares (1996, p.8) nos coloca:

"Estes métodos e/mu escolas de ginástica näo pensaram a Ginástica na escola. mas os pedagogos e os médicos bascaram neles os princípios básicos para elaborar os conteádos de ensino da escola.(...) Esta ginástica compreendia exercicios individuais. em duplas. quartetos; o ato de levantar e transportar pessoas e objetos; exgrima:danças:jogos é posteriormente, já no final do século XIX. os jogos esportivos; a mísica: o canto e os exercicios militares". (Soares, 1996,p. 8)

As infâncias vividas 30,40 anos atrás refletiam o contexto de uma estrutura social correspondente aqueles tempos, sem a tecnologia dos brinquedos eletrônicos atuais, as crianças fantasiavam situações da vida adulta adaptando-as a elementos da natureza disponíveis revelando o momento histórico e culturalmente demarcado.

"O objeto da pedagogia da Educaçāo Física e esportes, assim, se estende ao Se-movimentar do Homem, o que não implica num Homem abstrato, mas ao Homem que tem história, que tem contexto, que tem vida, que tem classe social, enfim um Homem com inerente necessidade de Se-movimentar" (Kunz. 1994, p.61) 


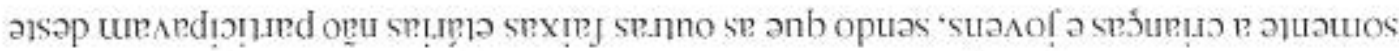

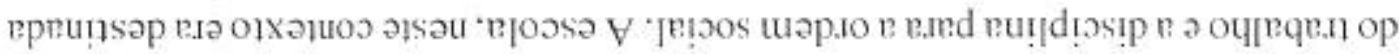

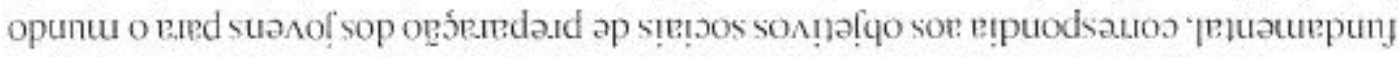

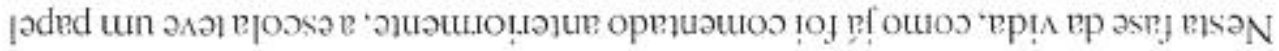

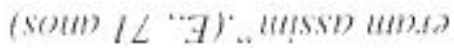

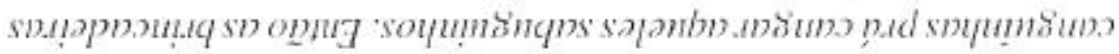

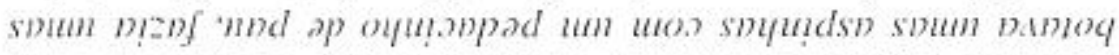

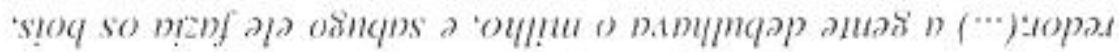

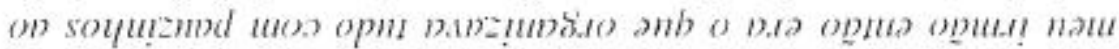
"1. muLu.

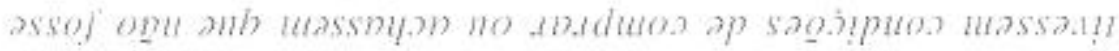

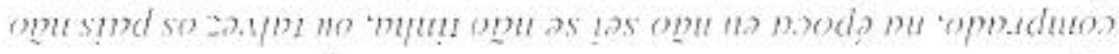

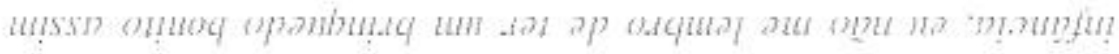

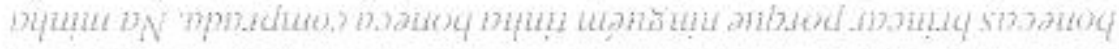
(4) Wm?

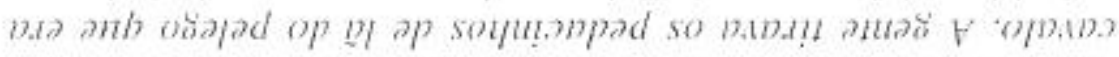

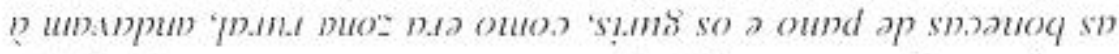

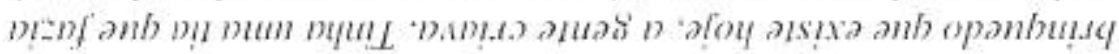

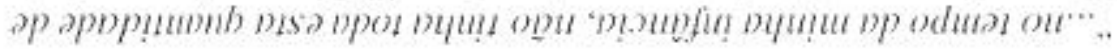

oxinq?

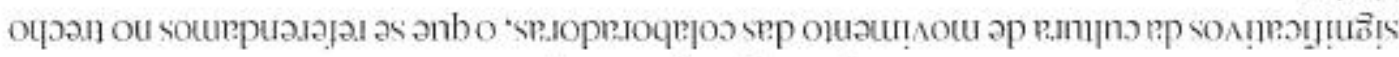

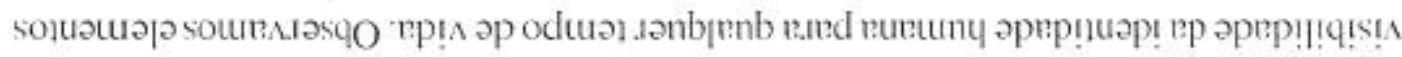

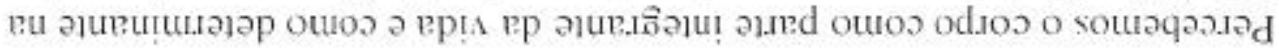

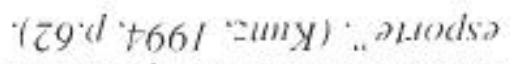

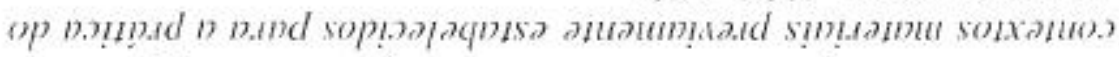

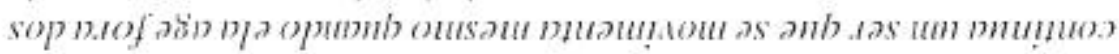

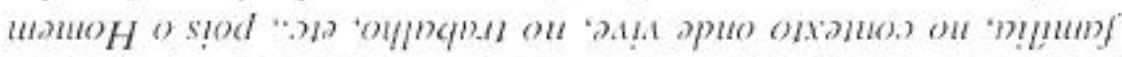

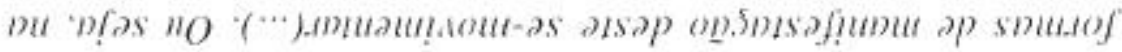

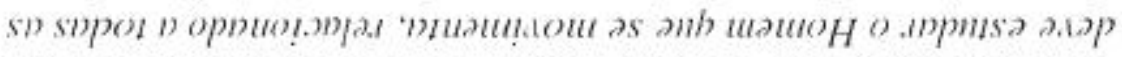

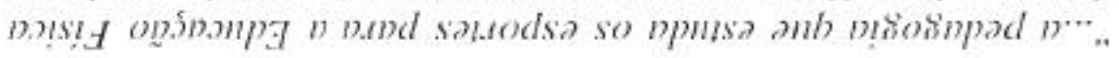

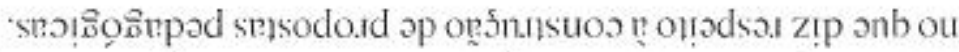

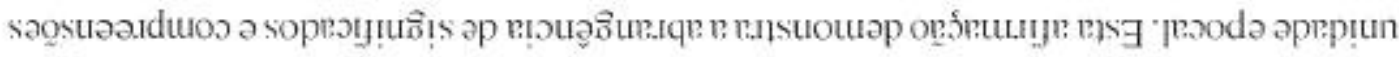

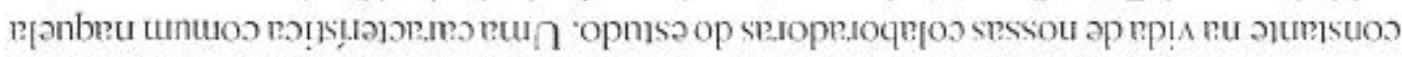

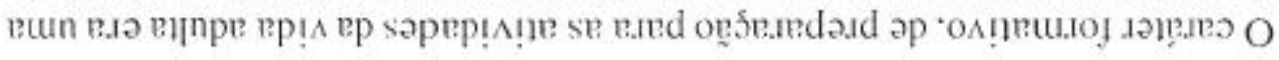


processo. As transformações sociais nos levam a redimensionar tais ohjetivos e pensar no conhecimento gerado na escola não somente como algo dado e acabado. O homem deve ser encarado na sta característica de inconclusão e o processo de envelhecimento precisa ser incluído nas discussōes desta instituição de ensino. As relaçōes intergeracionais fazem parte do mundo da vidat, porque não leva-las em conta na escola?

\begin{abstract}
"O papel da excola, nesta proposiçāo é fundanental no sentido de proporcionar às crianças e aos jowens un conhecimento antecijado do envelhecimento humano, daquilo que a vida naturalmente lhes reserva. ao mesmo tempo en que traz para o sen comvivio os avés, instituindo, desta maneira. dentro da escola. integração multigeracional, ande as proprios velhos tenham condicoes de twear sua experiencid de vide pelos noves conhecimentos que a escola lhes possa oferecer en temos de ana eduaction continuade". (bias. 1997. p.96)
\end{abstract}

O relato abaixo demonstra a participaçāo dos pais na educação dos filhos. Os valores, moral, bons costumes ditados na família são prerrogativas desta época. $O$ "movimento corporal" neste contex to deveria ser limitado, comportado, dentro dos padrões sociais previamente estabelecidos, Os relatos continuam evidenciando as brincadeiras que fizeram parte da educação das colaboradoras deste estudo:

"Na moda de antigamente, tudo de maneira bem simples, mas assim bastante saudáveis e educativas né. Unas brincadeiras assim que a gente brincava meninos com meninas, todo mundo brincava junto, existia muito respeito entre as crianças, a educação a gente sentpre tinha maita edacação de sempre respeitar muito os outros, de respeitar as pessoas mais velhas, e isso era um tipo de edacațão bastante diferente de hoje, mas eu acho assim muito válida, até hoje eu, muitas vezes sinto saudades em relação aos netos, de conno são criados hoje. que é bem diferente ,näo que a gente não tenha evoluido, mas eu acho assim que muita coisa antigamente que a gente aprendeu, muitos hábitos eu acho que devia ser conservado até hoje. São as coisas boas de bastante valor, principalmente o respeito. Eu acho que embora tenha que existir muita liberdade entre os pais e os filhos, mas eu acho que o respeito é uma coisa muito importante na vida das pessoas". (E,7I anos) 
Brincadeiras infantis, brincadeiras de roda eram muilo conuns e todos participavam. meninos e meninas sob o olhar dos adultos atentos. O valor saudável e educativo vem de concepções incutidas dentro de uma concepção de sociedade. onde o ousar seria um problema. Para fins de nossa reflexão precisamos avançar na compreensão do "mundo fenomenológico". bem como de corpoe de movimento.

"Compreconder o "mundo fenomenológices" das interpretaçöes naturais de am Se-movimentar como correr; saltar; nader; andar de bicicleta. etc., tem uma relevância didático-pedagógica muito grande. especialmente pelo entendimento de que este "mundo" se constitui para a criança e o adolescente. una forma muito especial

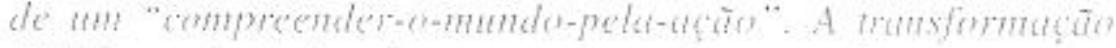
didaticapedagógica do esporte deve, em parte. lerer pare este

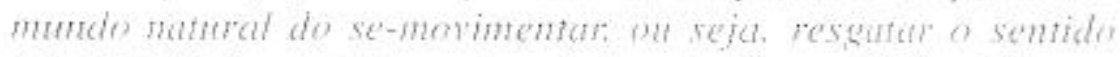

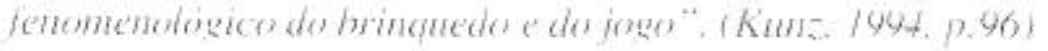

Algumas brincadeiras infantis eram aprendidas na escola e reproduzidas fora dela. Muitas delas padronizadas demonstrando que a Educaçāo Física atingia seus objetivos hegemônicos naquele período histórico, Os objetivos da Educação Física escolar ficam transparentes na citação que segue.

"Todo este "processo civili-anório" para dominas e controlar subjetividades acontece em forma de "rituais". pela formação de hábitos. (...) A éscola é basicamente formadora de automatismos. habitos e de rituais na vida do jovem que disponsa o pensar: Diferenças e singularidades individuais devem ser abolidas pela estratégia técnico-instrumental do processo de ensino, e assim, os valores hegemonicos podem ser homogenei-ados". (McLaren apud Kuñ, 1994, p. 107)

Para ilustrar o que foi dito anteriormente, no que diz respeito às brincadeiras dentro e fora da escola, citamos a fala da colaboradora.

"...fora da escola a gente fazia, aos domingos a gente se reunia, a gente brincava das brincadeiras que a gente aprendia na escola. As canções que a gente cantava, a gente aprendia na escola. A proféssora ensinava(...). "a menina tão galante, a..terezinha de jesus", ah... todas essas coisas assim que a gente cantava na escola,

KINESIS, SINTA MARLA, $N^{\circ} 25,200 I$ 
agente tanbém cantava nas brincadeiras de domingo. nos passeios que a gente faria. E depois foi passando o tempo, e deixei de ser menina..." (E., $7 /$ anos)

As infrações às regrăs sempre eram as mais divertidas e emocionantes e por isso fazem parte dos momentos mais lembrados pelas colaboradoras, o que revela um corpo considerado substancial, por imposiçāo. em busca de um corpo con "luz própria", ou seja na busca de sua dimensão relacional.

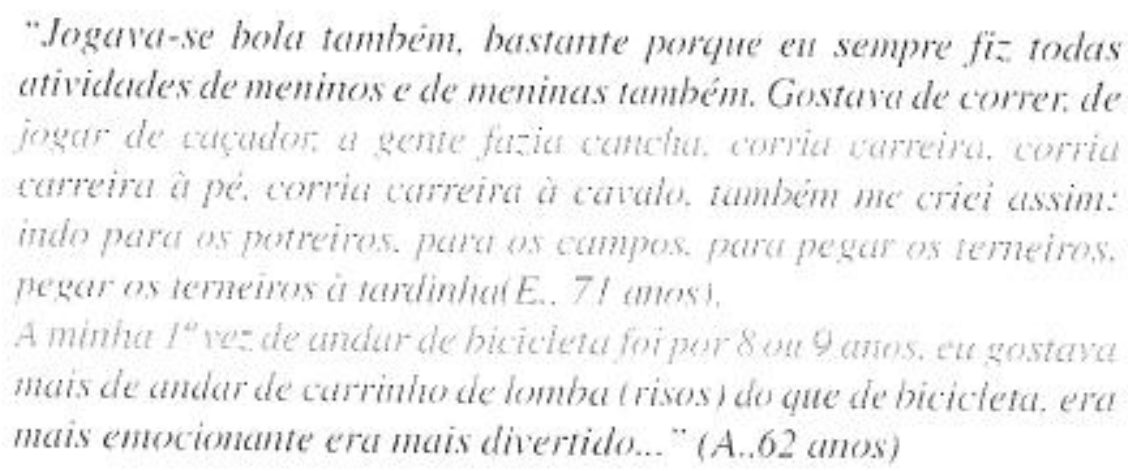

A disciplina, o controle de elementos subjetivos, imprevisíveis e sem controle. bem como a delimitação de possibilidades caracteriza determinaçōes educacionais, vislumbradas na prática pedagógica com objetivos bem definidos.

"Na excola, famtasias e desejos devem dar lugar a retenção de informações, nos chamados contéidos téricos e repetiçóos mecânicas nas disciplinas práticas como a Educação Fisica. A prática de exericios repetitivos vai retirando, assim, significados individuais nas realizações humanas. A relação de se-movimentar com a subjetividade humana é fundanentalmente uma relação de sensibilidade". (Kunz, 1994, p.106)

Além da escola e de seu papel evidente nesta fase da vida, não podemos esquecer de que também neste período, a participação nos bailes teve sua importância. A passagem de menina para moça acontecia no meio familiar e a transição era acompanhada de perto pelos pais.

“... com 15 anos, eu connecei a ir a baile. porque antes meu pai não me deixava, tinha que ser só com minha mäe, ou com un dos meus 
imǟos, assim mesmo com muito choro, porque eles não me largavan, ea tive ama criação muito presa, muito presa mesmo porque eu acho. que eu penso hoje. como mäe en penso quat anda de interdito) não é dessa maneira que se cria fillho, en acho que filho. tu cria conversando, explicando os perigos da vida rona de interdito) mas nāo com prisão, éu fui muito presa". (A.. 62 anos)

Estes depoimentos nos remetem ao aspecto temporal. histórico e cultural que ditam as regras social mente aceitas. Ficavam bem definidas as manifestaçōes corporais permitidas: baile com dança, mas acompanhada pelos pais.

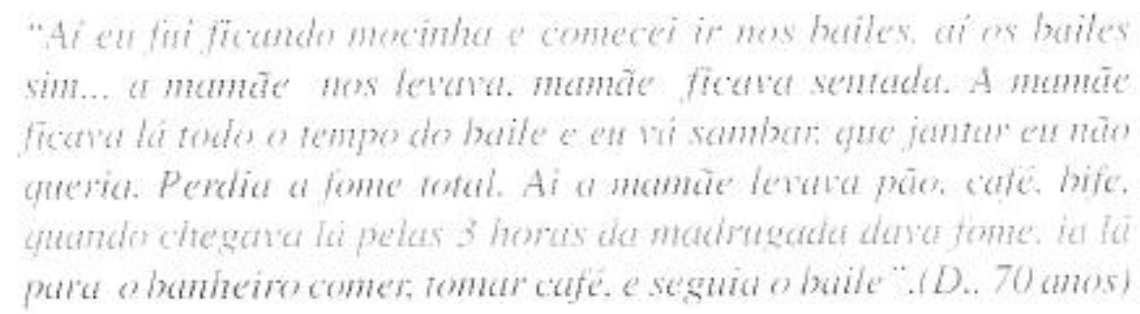

No depoimento anterior vislumbramos um "corpo" que "lutava" em sta perspectiva relacional, mas que é tomado de uma imposição substancial.

A transição de moça para mulher carregava sonhos: o casamento, para muitase a vida adulta cheia de sucesso através da vida de artista para outras. Estas etapas eram hem determinadas e deviam ser "vencidas" por todos, obedecendo a ordem natural dos acontecimentos.

"Nós brincávamos de pegador, estas coisas. Mas, a gente já estara ficando ficava mocinha e o papai achava que não era para estar correndo. AH!, ai eu descobri que estavam convidando as meninas na radio Farroupilha, difusora, jánem me lembro mais, que era no tempo do Bumba, aí eu quis, bancquei a cantora, fui lá. ganhara 50 pila, näo sei, há muitos anos atrás eu nem me lembro mais quanto é que era. Aí eu fui, fui concorrer".(D.. 70 anos)

A vida social e de "movimento" era marcada pela religiosidade e pelos bons costumes da família, sendo assim determinadas. Vale ressaltar que o advento do casamento era um papel determinado que logo deveria ser assumido. 
“...foi neste tempo, que eu passei dos 14 para os 15 anos que en conheci o A. ( marido) e a gente comegou o namoro, mas eu continuci estudando com 16 anos, no dia que en fiz 16 anos, eu botei as alianças, noivei, era no dia do men aniversarto, teve am baile e a gente foi comemorar num baile, com 16 anos. Tive am noivado. ele tava estadando tambim. né. Estava tirando enfermagem e...a gente fe- an baile muino bom ane ate hoje a gente... tem gratas recordações e depois casamos quando eu fi- 18 anos, quando eu fi- 18 anos a gente casou". (I., 79 anos)

O movimento na fase da juventude, e também na infância se confundem com os sonhose a fantasiat primeiramente as brincadeiras infantis, e depois or primeitos bailes. o inicio da inscrễo na vida dos adultos a eminencia do casamento algo desejadoe idealizado por todas as mocinhas.

Diferente do ontem pela distância dos anos, atualmente a infäncia e juventude sotreram transiomaçòes. 0 avanço tecnológico. a influência da midia distanciam as carracteristicas do "movimento" através dos tempos. Enquanto antigamente construían-se os brinquedos. subiam em árvores, hoje os brinquedos já vêm prontos e o computador oferece um mundo virtual a ser explorado e vivido limitando o ser de movimento a uma poltrona em frente a uma tela que se transforma a cada segundo.

Podemos inferir que no passado existiam muitas oportunidades de movimentos livres na natureza. Atualmente. a tecnologia nos trouxe muito conforto. mas também o sedentarismo, como um dos problemas mais sérios de nossa atualidade. Esta situação nos remete ao compromisso de redimensionarmos os objetivos da Educação Física para sanar todo o sedentarismo provocado pelo avanço tecnológico que dá suporte aos brinquedos infantis. Não devemos fazer juízo de valor sobre qual infância era melhor, a de ontem ou a de hoje, cada uma responde a seu tempo, por isso não podem ser comparadas em níveis qualitativos.

A partir de agora se configuram outros papéis e o "movimento humano" possui outras representações a partir daqui. O corpo como determinante na visibilidade da identidade caminha pro outros papéis no desdobramento social.

\section{Vida adulta...}

O corte horizontal imaginário da vida adulta de nossas colaboradoras, no que diz respeito às manifestaçōes de movimento demonstrou ser muito restrito e incrivelmente próximo um do outro. A dedicação ao lar, às tarefas femininas, o cuidado com a família representou os 
eventos mais importantes desta fase da vida. O trabalho ficou exemplificado por uma das colaboradoras que era professora.

"...aif fui traballhar, enconneceianamorar, depois fiquei noiva casei. Com 23 anos en me casei, mas ai continuei trabalhando igual, quando ea me casei, ande et morasa tinha umat escola perto, anda escola estadual raral, ai eu contimuara trabalhando, só que depois timha que whe deslocar dum lagar onde eu morata pra onde ea trabalhava, dai a gente ia de a cavalo, at tinha que it de manhà para o colégio, passava o dia, à tardinha voltava para a casa". (E. 7 l anos)

Realmente o advento do casamento demonstrou significar um marco ná vida das mulheres desta época. Com on casamento vem as obrigaçes de um boa esposa e donu do tur: mutus vezes outuros sonhos forum deixados de lado em nome de um destino conum às mulheres: matrimono.

"...quando fahtava un ano para me formar, eu me casei, encontrei o A. (marido). me conheci, nos conhecemos, casamos e ai eu parei de estudar faltando pouco tempo para me formar que depois ea continuaria, que não é como agora que lodas as coisas tem mais facilidade, com um ano de casada veio o primeino fillo. o Jamese ai eu tive que parar ai en engravidei, comecei a estudar de novo. veio o segundo fillho, naquele tempo näo tinha creche como agora não tem essas facilidades. näo tinha irmä mais velha. não tinha ninguém, era so eu. porque minha mäe dizia quem fez o fillo vai criar ela não... ela era uma santa criatura. mas ela não cuidava, era muito dificil para encontrar uma pessoa para caidar das crianças, então eu parei de estudar por isso, e até eu digo brincando como os expirifas dizem que há reencarnação, se houver reencarnação eu tenho que vir para terminar as coisas que eu nāo terminei e que eu teria vontade de terminar". (I., 79 anos)

Outro relato acerca da dedicação ao casamento:

"Eu casei em 1957. Eu me casei. Noivei dia 23 de dia 23 de março. e casei dia 8 de novembro de 57 , tive 4 filhos.... meu marido era muito, ele era gente, era uma pessoa que gostava de viver de 
aproveita; de ir a baile, ele era gente da noite, muito desportista. então Domingo éu não tinha marido. porque cle estara nos campos de futehol. (...) eu pegava meus filhos e saia. graças a deus ele sempre foi una pessoa que nunca me proibia nada, foi até muito companheiro, muito amigo (enteçäo) (...) porque a gente com 4 filhos se movinenta muito, a gente nāo para manca".(A.. 62 anos)

As rotinas da casa, com as tarefas não remuneradase tantas vezes desgastantes demonstraram ser a escência da vida das mulheres nesta fase. O corpo nesta fase representa a sua subordinação ao trabalho. Vislumbramos a perspectiva substancial de corpo. onde o movimento constitui tarefa com relação técnico-intrumental. Ou seja, o corpo enquanto instrumento de trabalho.

Fica clara a diferenciação de papéis sociais entre a juventude e a vida adulta. uma vez que esia última representa a ligaçăo e o compromisso con on mundo do trabalho

"No pempo de crianca sime, fisica wolei comidas, aquelas conisas" assim e depois de casada. depois de mocinha. a minha ginastica era o baile.e depois de casada só a motina da casa. faser connida, limpar: Tarefas do Lar? É. rotina. é conno eu sempre disse e digo en era una empregada doméstica sen ordenado. Para mim, näo valia nada isso ai, on era un compromisso, o exemplo do lar, a gente via sempre o papai e a mamãe trabalhando ou seguia aquele ritmo que en achava que devia e não me arrependi de ser esta esposa, não me arrependi mesmo". (D., 70 anos)

Nesta fase, podemos dizer que o corpo e o movimento ficaram estreitamente ligados a tarefas e obrigações, hábitos sedentários, a corporeidade presa a normas e regras sociais. Muito pouco se observou de diálogo com o corpo, prazer no se-movimentar ou experiências similares, obedecendo a ordem ditada e permitida. Mais uma vez vislumbramos a perspectiva substancial de corpo.

"Tudo deve, de certa forma, ser controlado nas pessoas "adultas" e "sérias", em especial, aquilo que toca os sentidos, que desperta a sensibilidade, o que fascina, ou que repulsa, o que assusta, ou o que causa arrepios, etc. Tudo isto é totalmente desconsiderado na formação das subjetividades, através da educaçāo escolar: Assim como a descontextualização, o desconhecimento da idéia de história, a ênfase no individualismo e na competitividade, a ausência 
de emoção, o autoritarismo, a desmoralisação do ego e a supressão de contradiçöes das instâncias fornadoras de subjetividade. culminam para uma formação estereotipada do ser humano. " (Kunz: 1994, p. (04)

Os bailes, por stát vez. estavam presentes nat vida de algumas de nossas colaboradoras participando ou acompanhando os filhos nestes eventos sociais. O baile constituía uma manifestação social permitida e prevista, onde as relações eram préestabelecidas e impregnadas de automatismos que revelam uma identidade vinculada a uma concepção estereotipada.

Um depoimento interessante foi o de E. ( 71 anos), que quando era professora voltou a fazer ginástica com seus alunos assim. mesmo sem oportunidades especiais exercita-se por prazer ensinando aos alunos a liçāo de cuidar do corpo.

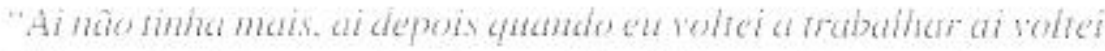

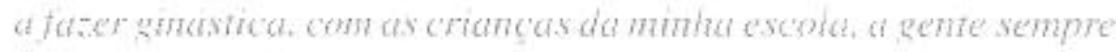
fa-ia com as crimças. A gente mesmo criana os exerwios, agente fa-iania para o pátio, ai faria fila com eles. a gente ensinara a cantar a..no pátio. quando éra semana da pátria, principalmente. a semana da pátria. todos os dias da semana da pátria, tinha aquelas atividades com jogos que a gente, a gente... não é que a gente inventasse a gente comprava uns livinhos que ensinava jogos para as crianças, ensinava canção, então a gente fazia bastante exercicio com eles ai, ia para o pátio, aí a gente fazia corrida com eles, a gente fazia... apostava, jogava, um grupo ia para um canto do pátio, outro grupo para outro, ai fazia brincadeira pra ver quem ganhara, corria bastante, né. fasia muitas brincadeiras, assim de...ginástica, de braço. de perna né. brincadeira roda né. ai a professora fazia junto com os alunos." (E., $7 /$ anos)
\end{abstract}

Nesta fase a Educaçāo Física nāo teve espaço na vida das pessoas, pois diz a regra social que aulas de Educação Física são para crianças e jovens. Não existem espaços e as pessoas devem se preocupar com a família e o trabalho, o corpoé mero instrumento a disposição de papéis sociais demarcados para esta etapa evolutiva.

\title{
Velhice...
}

Este é talvez o corte temático etário mais significativo deste estudo, uma vez que 
as colaboradoras deste estudo são pessoas que estão ativas e participando intensamente das atividades. Elas são o exemplo de una época que esqueceu o antigo e ousou o novo. começar projetos antes considerados de propriedade dos jovens, aprender coisas novas e que dão prazer, re-descobrir o corpo, sua morada, sua maneira de ser e se relacionar com os outros. Nascem novas perspectivas de linguagem e comunicação com o mundo. elas demonstraram que é possível viver maise melhor seus anos.

A Educação Física foi "recrutada" nesta fase,por causa do aumento do tempo livre de obrigações. Percebemos uma necessidade emergente de propiciarmos às pessoas vivências do seu corpo. descobertas e aprendizado de novas experiências.

"A aprendi-asem permanente, para as pessoas idosas, toma-se uma questano wital. Aprender é assimilar nowas valores idétus e contiç̧es pessoais. E dificil aprender a emethecer poryue as mudancas atie ocorrem. cansam medo is pexsass. dai, a resistencia a aprender: As pessoas recusam-se a travar dialogo com as novas

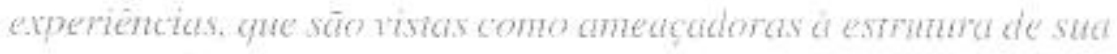
personalidade. Aqueles que tôn a coragem de inictar tal dialoges. encontram, durante o processo de envelhecimento, uma vida cheia de novos desafios e compreensōes. " (Dias, 1997. p.61)

Devido à acelerada transformação e a pressão de uma demanda, a Educação Física enquanto área até então restrita a formação escolar, vê-se diante de um impasse e de um desafio muito grande. Historicamente a Educação Física obedeceu a objetivos bem definidos, dependendo do momento social que se estava vivendo. Primeiro a influência militar, que impôs sua cartilha às escolas e depois o período de esportivização, mais tarde a crítica, o surgimento da psicomotricidade como opção para suprir uma falha no desenvolvimento das crianças, as críticas sem propostas, as propostas utópicas, novas experiênciás... Tentativas da construção de uma identidade necessária. Neste momento histórico, os idosos surgem em seus movimentos organizados, como se fosse uma avalanche de cabelos grisalhos clamando pela ampliação de um espaço que se encontra em crise, a Educação Física.

O desafio reside no fato de não somente proporcionarmos espaços de convivência e de contato interpessoal/integração social, a proposta deve transcender e ser um espaço pedagogizado de transformaçāo, de criação de novos projetos, numa concepção de educação permanente, não queremos apenas ocupar o tempo até que a morte chegue, queremos viver este tempo aprendendo mais e mais ser gente e viver melhor:

A desmistificação de preconceitos e mitos sociais relacionados com a velhice está em ousar fazer coisas que até então eram propriedades de quem é jovem. Dançar, jogar 
bola, equem sabe até andar de bicicleta...

"(...)entäo aí él disse é vou comprar uma bicicleta para mim, para eu näo andar caninhando, est vou entregar minhas coisas, eu vou botar ama cestinha, vou botar meas produtos do Avon. vou entregar era bacana ne?" "( $D . .70$ anos)

Novas perspectivas são apontadas pelas colaboradoras do estudo, novas significaçōes do seu movimento, por exemplo, para a colaboradora (D., 70 anos), a bicicleta na infância tinha um sentido. agora redimensionado por outro momento de sua biografia, transformou-se de brinquedo a instrumento de trabalho e de emancipação.

O movimentar-se na velhice assume caracteristicas diferenciadas das outras faixals etárias pelo fato de que o sujeito possui una historia de vida. ou seja. $60,70.80$ anos de vivências. A individualidade fica cada vez mais evidente com o passar dos anos. A oportunidade de movimentar-se significa experimentar o diálogo com o mundo e aprender:

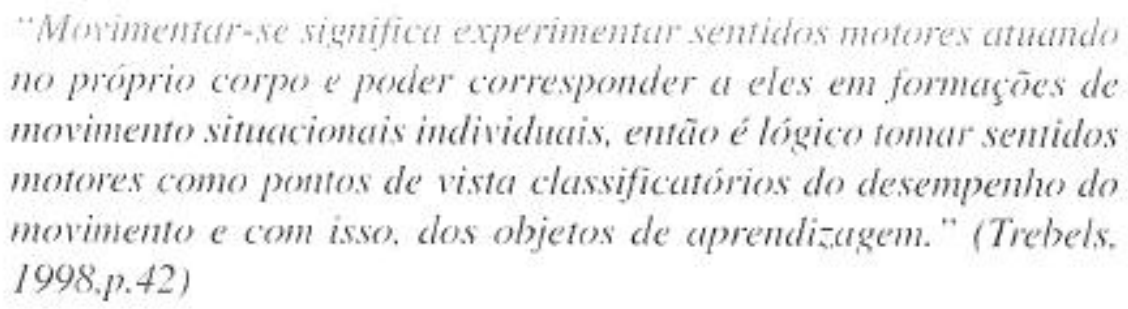

Em cada ruga no rosto, nas manchas senis pelo corpo, na flacidez de sua musculatura estão marcadas e simbolizadas suas biografias, seus aprendizados. Em seu íntimo guardam-se as lembranças do vivido e não-vivido e os anseios pelas realizaçōes que ainda pretende e precisa alcançar.

"(...)eu sinto assim (...) eu estou em movimento, porque senão como se di:.: .. nós não somos ferro, mas enferrujamos ?" É o que dizem ...vai paralisando nosso organismo, então esta é aparte q eu não deixo de fazer e quando eu estou dentro de casa, que eu estou camsada da universidade, não faço essa ginástica ali. as eu faço muita ginástica de dança, eu danço muito, todo dia assim eu estou dançando, e o meu interior fica sempre alegre. Porque tem coisas que às vezes parece que quer te derrubar. e quando eu sinto isso eu boto mísica e danço toda casa que aí eu espanto a tristeza. "(D.. 70 anos) 
Entre os idosos, a Educação Física muitas vezes é procurada por motivos de saúde, onde o médico indica como terapia o exercício físico, assim os idosos sāo obrigados a adaptar-se em umá nova realidade de movimento e descobrem que não conhecem as potencialidades, nem os limites de seu corpo. Temos a nossa frente algo mais que uma máquina a ser consertada ou para fazermos at sua manutenção, temos pessoas que sentem. choram e mesmo sem saber podem investir em novos projetos. Uns chegam assim: por indicação médica. outros para fugir da solidāo. outros querendo vencer os preconceitos referentes à velhice, outros ainda não saíram de suas tocas, seus nichos criados para proteger-se da vida aqui fora os objetivos como observamos em nossos alunos e nas colaboradoras deste estudo vão sendo redimensionados a medida que mediatizamos nossas relaçoses com eles e com o mundo. demonstrando a possibilidade de outros investimentos. Ainda não vejo como algo acabado perfeito. acredito estarmos no caminho, na iransiçāo de um novo tempo e tenho certeza que daremos exemplo de concepção de homem e educaçăo quando sensibilizarmos as pessoas de que aprender é larefa permanente é ela que caracleriza a vidà, a evoluçāo do ser.

Outro fator preponderante no trabalho da Educaçào Fisica com a terceira idade e que nùo constitui um dado apreensível são as relações subjetivas que acontecem durante o evento aula e também fora dele. Por exemplo, a afetividade possui papel fundamental no trabalho com a terceira idade, uma vez que os idosos com os quais trabalhamos demonstram a necessidade do "toque". do "carinho" para sentirem-se "vivos" e importantes no contexto. Podemos inferir que tais elementos encontram-se intimamente ligados ao foco de "resgate" de vivências corporais e sensíveis com o outro e consigo mesmo.

Uma vez considerando os fatores subjetivos, entre eles, o da afetividade e da moral, entendemos que interferimos nos caminhos de elaboraçăo pessoal. no sentido da redescoberta e descoberta de novos valores que norteiem a vida destes indivíduos idosos. A emoção, a transpiração, os olhos marejados de lágrimas, as gargalhadas, ou mesmo a indiferença demonstrada em uma aula sāo indicadores que elementos subjetivos que se encontram inseridos no contexto pedagógico. Surge então o questionamento: como trabalhar com tais elementos? O paradigma das ciências naturais com certeza não contempla tais aspectos, nem os considera.

Consideramos ponto fundamental e basilar conhecer quem é o nosso aluno não somente sob a ótica do visível e observável, mas também adentrarmos em sua subjetividade, nas vivências passadas, na história pessoal construída, nos anseios, nas pretensões de vida.

É notório que existem particularidades que diferenciam as orientaçōes da aula de Educação Física com individuos de idade avançada dos indivíduos que ainda encontramse na infância e adolescência. As diferenciações estão no significado e no sentido do 
movimentar-se, porém vale ressaltar que o movimento é propriedade humana. e. portanto independente da idade.

Entendendo como verdadeiro o parágrafo acima podemos inferir que as discussōes sobre Educaçāo Física com a Terceira Idade não podem acontecer paralelas à discussão de Educação física em seu sentido mais abrangente. Atualmente o foco principal nas intervençōes nos "movimentos da $3^{3}$ idade" encontra-se voltado ao resgate de elementos elaborativos de desenvolvimento que se encontraram "atrofiados" nasetapas precedentes dociclo vital.

Tendo em vista esta constatação, estão entre os seus objetivos os resgates de experiências corporais negadas em etapas anteriores da vida. Na fala das colaboradoras percebemos neste fato no corte horizontal feito na vida adulta na discussão deste estudo.

Ao resgatar velhos projetos estimular novos durante as aulas de Educação Física. enfatizar as possibilidades em detrimento das limitaçōes é uma premissa básica. As possibilidades nascem do impulso pessoal. o idoso precisa querere estar aberto ao diálogo com o mundo. Ao professor resta esimular, dar confiança e seguranç e oportunizar espaços de movimentar-se para que o dhálogo aconteça.

A participação nas atividades oferecidas pelo NIEATl constitui um evento muito importante e decisivo na vida das colaboradoras deste estudo, como podemos perceber nos relatos que seguem.

"Não digo assim. logo que abriu, mas acho que ant ano e meio ou dois. Em 85. 86, É por ai, en já entrei e näo parei mais. Ai fiquei lá na universidade participando e participo na comunidade. também a gente tem un grupo de gincistica.(E., 71 anos)

(...) eu me matriculei na natação. naquele tempo, a gente fazia inscrição a gente näo tinha carteirinha com foto nem nada. E eu fui e o Juca deteminou que duas moças la da educação física trabalhassem conigo na a gua, elas tinham que me pegar pelo braço e me ajudar botar uma perna no degrauzinho, até que eu me jogava na água... Começaram a me trabalhar aos pouquinhos..." (1. 79 (nos)

Principalmente com o avanço da idade, onde o declínio biológico é um fato, a saúde torna-se alvo de importante atenção. Ela é uma competência que aliada a outras, emancipa o homem para as atividades que sonha realizar, ela é a chave para a autonomia, liberdade e ação, sem elas temos dificuldades de nos relacionarmos e aprendermos coisas novas, este aspecto é muito importante e fundamental para futuros projetos. 
"uns 8 ou 9 anos atrás, eu tive um problena de coluna, na cervical. muito triste e doloroso, eu fiquei sem caminhar: passei... acho que meses nacama equando queria ir ao banheiro e dependia de pessons para me botarem num banquinho dentro do box e com(confuso) chuveirinho me dar banho, por isso até agora en digo, se um dia eu ficar mais velhar una coisa que ea não queró é depender dos outros, que tenham que me dar banho, que é a coisa mais wiste a gente depender de uma pessoa. esfregar a gente. ensaboar a gente, a sente ficar inatil até para secar un pé." (1., 79 anos)

Sobre a atividade física na vida das colaboradoras, os relatos evidenciam a melhoria da qualidade de vida a partir da incorporação de sua prática. Vejamos o relato a seçuil:

"Ah. en acho importantissimo. porque ele melhora. methora tude.

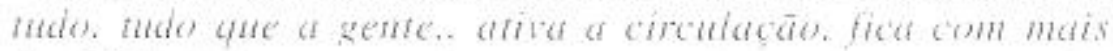
flexibilidade.para se morimenar para tudo porque se a gente não

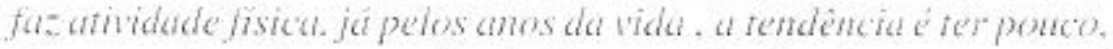

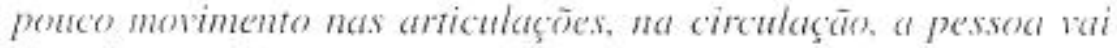
ficando parada e rai surgindo as doenças.e fazendo atividade a gente não, não tem tempo de ficar doente, porque o organismo fica täo em forma, que tu está sempre em forma, tu caminha com facilidade, tu corre com facilidade né?" (E., 71 anos)

Existem pessoas que são exemplo que a velhice não é sinônima de estagnação,e nos contam um pouquinho de seu cotidiano, demonstrando que estão "vivas".

"(... jeu so tenho livre, as sextas feiras, porque eu jogo bocha, nos sábados eu treino e nos domingos éu jogo lá nas Dores. Eu jogo bocha a uns três anos, que eu comecei a jogar bocha, é um esporte que eu sempre detestei, não gostava. porque antigamente a bocha só era nestes barzinhos de terceira categoria e então eu sempre tive um preconceito com esta atividade de bocha e por ironia do destino. eu estou jogando bocha (risos) Eu faço hidroginástica eu me sinto melhor ainda, então a hidroginástica, juntamente com a nataçäo é una terapia incrivel para a coluna, eu nunca mais tive problemas de massagem. A atividade física é tudo para mim, é uma terapia. tanto para minha cabeça como para meu corpo. Eu gosto, eu adoro, a dança, eu acho que a dança é a coisa mais linda que Deus inventou, 
porque tudo que nós temos é criação de Deus." (A., 62 anos).

Outro relato que nāo pode deixar de ser lido:

"Hoje, eu levantei hoje, às 6 horas, levantei. tomei meu banho, ai peguei o suco que estara pronto. tomei am copo de suco. tomei meu medicamento e ai às 6.30h mais ou menos sai de casa. Peguei un ônibus, fui pra lá pra universidade, fiza aminha caminhada. andei $3 \mathrm{~km}$. depois fui pra natação. Fis nataçāo das 8:30 até às 9:30. Das 9:30 até às 10:30 fir musculação. De lá vim de ônibus até o centro, no centro circulei bastante na cidade. Tinha umas voltas

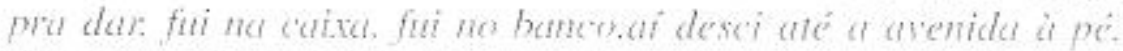

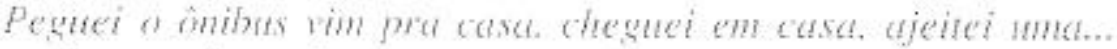

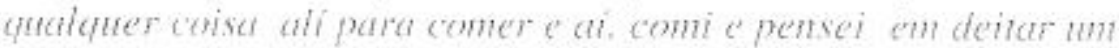

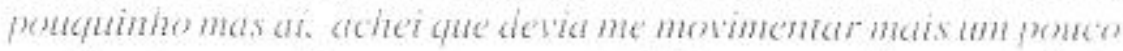

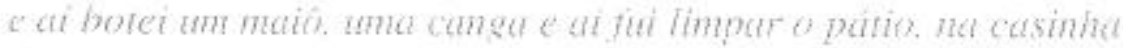
do cachormo, fini lavar ap piso onde o cachome anda, fui lasar a casinha do cachorro, dar banho no cachorro e at troquei e rostpa, fui para o centro, tinha unas atividades pra fazer e at voltei porque ja tava na hora da Claudinha chegar para me entrevistar; e agora. já estamos sentadas aqui tomando chimarrão. Agora vou para a ginástica. das 5:30 às 6:30 tem ginástica com meu grupo grisalhas da primavera. Foi o primeiro grapo. que nasceu, é o grapo semente da cidade. Foi o I". O professor Juca se espelhou nele para que os outros existissem. Então, o nosso grupo é atuante. Entäo eu ainda vou das 5:30 até às 6:30 e depois venho para casa. Ainda acho que vou na vizinha, ela tem uns negócios... Ainda entrego dizimo na comunidade né, ai tem uma rua que eu que entrego dísimo, depois que eu voltar da ginástica ainda vou fazer mais uma caminhadinha para entregar o dízimo. Enfim...Ai vou sentar pra tomar um matezinho, ai acho que deu pro dia!' gargalhadas)" (E.. $7 /$ anos).

Devemos respeitar as histórias que carregam dentro de si, os sonhos muitas vezes negados em outras fases da vida, sem a pretensão de resolver todos os problemas sociais, a Educação Física que chamaria de permanente não ensinaria ninguém, apenas seria o despertador para as descobertas de cada um. 
"Ea sonho, desde nova. quando ea fï- 15 pra 16 anos en acho que

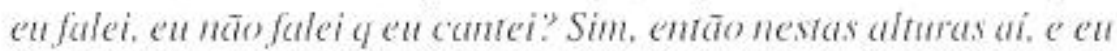
continuo com este sonho, tanto que a universidade esta me dando esta chance, que eu faça minhas mimicas, que eu gostaria de cantar sem mínica, mas pra isso en tinha que aprendert...) o violonista tocar e eles me ensinarem a entrar; a sair é preciso. porque me da assim am sistema nervoso me da um branco e fas com que ea esqueçar...) tenho pairão por teatro, mas eu gostaria de teatro assim do momento, e q mais bom, a universidade é a túnica que me dá chance de eu ser essa tal artista que eu quero ser, ea ja son assim universitária? E eu sou felis por isso." (D. 70 anos)

Soares (1996) também partilha da idéla de que viver e aprender caminham juntos. indissociaveimente, e nos coloca esta idéla no trecho a seguir.

"Assime penso que estamos sempre aprendendo e so de ixamos de fase-lo quando morremos. Estar live é. sabretudo. extar aprendendo. Mas ha diferentes saberes no mundo em que vivenos e há também máltiplos itinerários para sorve-los, para neles mergulhar:" (Soares. 1996, p.6)

A mesma autora se reporta à escola como auxiliar nesta sinalização e como um lugar contextualizado e conectado com a dinâmica das transformaçōes sociais.

"Talvez a escola padesse auxiliar nesta sinalizaçăo, pudesse ser um lugar onde se vai para aprender coisas, coisas que näo se sabe ou que, se sabe apenas na superficie. A escola então seria um morno oceano onde se mergulha para conhecer: Como não se chega vazio até ela, este mergulho não é cego... ele é parte de um impulso humano para aprender:" (Soares, 1996, p.6)

A inclusão de propostas de Educação Física para/com/na terceira idade representa uma mudança de compreensão de identidade e legitimidade da Educação Física, pois, pensar em uma educação/educação física para/com adultos é pensar em educação/ educação física para crianças e jovens. Entendemos que a recíproca é verdadeira, pois o caráter inacabado do ser humano e as competências deve ser despertados e estimulados a uma constante transformação/evolução através da história de vida de cada sujeito. Esta assertiva se encaminha para o que compreendemos como Educação/ Educação Física Permanente.

KINESIS, SANTA MARIA, $N^{\circ} 25,2001$ 
Neste novo mundo que se abre fazendo da Educação Física, que prefïro denominar de permanente,um espaço de aprendizado, não precisamos justificar nossas intervençôes, elas estão justificadas nas mudanças nas vidas daqueles que aderiram. que acreditarame acreditam que podem muito mais. Estanos construindo um caminho, mas como disse anteriormente penso estarmos na trilha certa. a das incertezas, a do respeito à complexidade das relaçōes humanas.

\begin{abstract}
"Eu por exemplo, nos meus $7 /$ anos descer daqui correndo até la para pegar o onibus, eu canso de fareer isso, sabe. Quando eu me aposentei e tirei a carteirinha, de 65, quando eu fui pegar a primeira ves a I ves que fui pegar: o motorista me barrou na porta. "mas

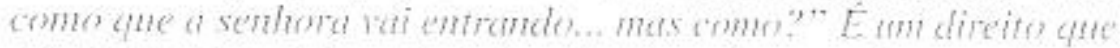
me axiste the umige, Eu tenho 65. "A senhort weio correndo. ent via senhores vir correndes de la perto da sua case, a senhora descente "arrendo toda e a senhoras rai cutrar pela trente." Me barron na pora entäo. A gente sente que a atividade tisica... Isso caminia fado a lado com a gerno. E pena que a gente nä́ fe- essa atividade lá dentro da barriga da màe, não é." Na época a gente nä́o sabia. que isso era täo bom!' A gente...existia as coisas, mas a gente não tinha conhecimento de que isso era bom para a saide.. Então agora a gente não para mais. depois que a gente começou, eutenho cerlesa que quem não fá é porque näo provou. Depois que prova nunca rai entrar na idade do condor com dor aqui, com dor ali, porque näo deu tempo, ahh. näo tem mesmo," (E. 7I anos)
\end{abstract}

Na história de vida das colaboradoras observamos o corte temático da "cultura de movimento" e constatamos que muitas histórias se repetem por retratarem os mesmos períodos históricos, as histórias individuais transparecem no decorrer dos anos onde as histórias se bifurcam e voltam a encontrar-se na participação nas atividades oferecidas pela Universidade através do NIEATI.

Através do desvelamento desta realidade, percebemos que através das transformações da sociedade, o homem cria e faz história, enquanto ser histórico-social, conforme nos coloca Freire (1987)

'Através de sua permanente ação transformadora da realidade objetiva, os homens, simultaneamente, criam a história e se fazem seres históricos-sociais." (Freire, 1987, p.92) 
As idosas colaboradoras. enquanto contavam parte de suas vidas reproduziam as unidades epocais, com seus universos temáticos interdependentes dos aspectos históricos e culturais. A dinâmica e a complexidade das transtormaçỏes sociais nos permitem projetar um futuro dinâmico onde a educação. enquanto um "quefazer" permanente tem papel fundamental na construçāo da emancipação e liberdade do homem em todas as idades.

"Assumir a fase da velhice. daqui para frente requer a nitida sisão de que estar bem na velhice tambèm näo é coisa só de quem está velho, é antes de tudo ter a consciência de qué é preciso prepararse para tal e. principalmente, estar consciente de que as grandes maíorias dos velhos, por certo näo estarão tão bem ou nada bem,

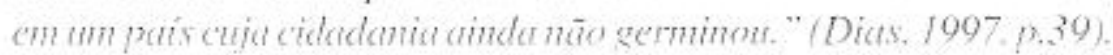

São as mudanças nas concepcones de velhice e envelhecimento que começam a ser fomentadas no meio social. Na Élucação Fisica, concepçōes de corpo de movimento adicionadas com as referidas mudanças provocam um redimensionamento nos conteúdos. métodos e no ensino. exigindo que ur reflexāo específica que está no contexto social abrangente, com a desmistificaçâo dos mitos e preconceitos referentes à velhice.

"O modelo de velho que vem surgindo não é no sentido de una gerontocracia, mas no sentido da maturidade intelectual, espiritual. contemplativa, firme, dócil, latadora, mas principalmente uma fase da vida que tenha luz própria para poder iluminar seu caminho eo caninho dos outros." (Dias, 1997, p. 39).

Observamos a contraposição entre a história de movimento na fise da juventude e vida adulta. onde o movimento possuía uma relação instrumental, onde a imagem de corpo dominante era substancial, e a fase da velhice, onde as compreensões de corpoe movimento começam a ser redimensionadas a partir da mudança de paradigma, caminhando rumo a um paradigma fenomenológico de movimento. Neste paradigma, a Educação Física amplia seus objetivos e passa a ter o compromisso de proporcionar um espaço para o desvelamento do ser.

Em uma discussão que pretende ser propulsora de uma discussão de Educação Física Permanente, os trechos de depoimentos aqui contidos demonstram ser o início da busca de uma identidade e legitimidade de Educaçāo Física que não imponha limites etários e que prime pelo desenvolvimento do homem.

KINESIS, SANTA MARIA, $N^{\circ} 25,200 I$ 


\section{SEM CONCLUIR}

Sem concluir, declaramos que é urgente tratar com seriedade e compromisso a inclusão dos idosos no "mundo da Educação Física". O desenvolvimento de competências. a autonomia de ação e a conseqüente melhoria da qualidade de vida dos sujeitos em envelhecimento estàoem questầ.

A idade traduzida em anos em termos de quantidade. não garante experiência em quantidade qualidade de movimentos, encontramos muitos alunos sexagenários que pouco dialogaram com o mundo através do movimento e isto devemos atribuir a múltiplos fatores, que associados nos remetem ao compromisso de oportunizar o resgate de histórias que não foram vividas, diálogos que não aconteceram. corpos que não se movimentaram. sujeitos que não se relacionarum.

Os fatores aos quais nos reportamos sần as fortes infîencias sociais. culturais. regionais economicas e morais impregnadias na vida dos individuos. A muiher principaimente sofreu muitas restriçōes no que diz respeito a movimento corporal. o casamento precoce e os "deveres" de uma boa moça futura mâe nào deixavam espaço para outras atividades que ampliariam sua "cultura copporal" ou ainda. "cuitura de movimento". como diria Bracht (Coletivo de autores. 1992). É preciso pensar nas concepçōes que norteiam nossa práxis: o que entendemos por homem, educação, sociedade, movimento, corpo/corporeidade. Estas constituirão nossas opções pedagógicass

Sabendo que não é possível a neutralidade de valores quando nos referimos a opções pedagógicas. c. portanto, às concepções citadas anteriormente, os leitores podem perceber quais os nossos posicionamentos acerca da temática. Resumidamente: compreendemos o homem enquanto se histórico cultural, inacabado, marcado por sua biografia: a educação como um evento permanente da existência humana; a aprendizagem como o "resultado" do diálogo do homem como mundo. Em resumo estamos abandonando o paradigma das ciências naturais para nos apoiar em um paradigma da reflexão fenomenológica do movimento.

A partir destes entendimentos, temos uma visão pedagógica de movimento. Nesta o movimentar-se, saber o porquê e para que nos movimentamos, permite o desenvolvimento do sujeito a partir de uma relação de diálogo com o mundo. Neste as significações e as necessidades aparecem em uma disputa subjetiva, e através dela, experimentamos $\mathrm{e}$ "crescemos". Em particular na velhice, a oportunidade de se movimentar contribuiria no desenvolvimento da autogestão e da autonomia, fundamentais para a eficiência nas tarefas que vivenciam.

Na velhice, o contexto situacional e o sujeito como ator de dono de suas açōes são importantes, porém, basicamente é o sentido e o significado do movimentar-se que norteia impulsiona a viver sua corporeidade e legitimar a unidade homem-mundo, fazendo 
com que o mundo seja compreendido em suas transformaçôes através do contínuo diálogo que transforma também o homem.

Poderiamos pontuar também: necessidades, desejos, expectativas, interesses e a história de vida de cada idoso. A partir destas premissas, percebemos a complexidade de relaçōes que se dão a partir das opçōes pedagógicas e da contextualização históricocultural.

Não acreditamos que a EF seja a solução mágica para todos os problemas sociais, econômicos. de saúde e culturais dos velhos em nosso país. buscamos que a aula de EF seja um espaço de oportunidades de desenvolvimento a aprendizagem, um espaço de movimentar-se, de descobrir-se de auto-organizar-se.

Entendemos que a Educação Física pode configurar um papel fundamental na vida das pessoas. Acreditamos que ela pode ser muito mais do que uma disciplina técrica que condiciona corpo ensina a reproduzir movimentos esportivos pré-determinudos. Ela pode propiciar uma constante descoberta do "eu" e de suas possibilidades. promovendo a autonomia corporal. A Educaçio físicu que se pretende permanente deve desenvolver/ despertaf as competencias do bem viver. para finalmente alcançarmos a autonomia, emancipaçāo liberdade de ação através do movimento.

Crescer, desenvolver, progredir, apreender, envelhecer são constantes na existência humana. Este contexto do ciclo vital é o palco das ações educacionais. O educador deve levar em conta a totalidade do ser humano, e também o seu caráter de inconclusão, para que sua ação repercuta em uma educação que vença preconceitos e quebre os tabus que mantém o velho segregado na sociedade. Baseados ná convicção que aprender é uma tarefa de quem está vivo, e, portanto não exclui os idosos, precisamos desenvolver ações educativas que contribuam de maneira efetiva na autoconstruçāo corporal e autonomia dos sujeitos que se encontram na faixa etária mais velha.

Entendemos fundamental a inclusão de outras faixas etárias, que não a da infância e juventude, na construção das teorias da Educação Física, uma vez que o pensamento excludente de grupos etários mais velhos perpetua o caráter formador da prática pedagógica, como se o movimento contribuísse para isso. Pensar uma Educação Física enquanto intervenção pedagógica e não somente técnica continuada, permanente, inacabada como o próprio homem o é.

Entendemos que não podemos pensar em uma proposta pedagógica especial de Educaçâo Física com idosos. Estaríamos ferindo nossas convicções pedagógicas. Concebemos o homem como uma construção inacabada, a educação como evento permanente de desenvolvimento deste homem, ser histórico e cultural e a Educação Física como espaço de se movimentar num diálogo com o mundo, na busca do desenvolvimento do que denominamos de competências do bem viver. Competências estas, a saber: objetiva, social e comunicativa. Para tanto, devemos pensar uma Educação Física que denominamos 
de permanente, mas poderia ser continuada, inacabada, etc. Esta proposta em nosso entendimento deve estar baseada em um paradigma da reflexão fenomenológica do movimento. e mais, que ultrapasse os muros das escolas e adentre na vida das pessoas. em todas as idades. Almejamos que as discussões sobre a Educação Física se ampliem e questões relacionadas com envelhecimento humano, e também com a vida adulta figurem naturalmente no contex to geral de reflexão das proposlas de Educaçâo Física.

Além destas verdades que preferimos chamar de provisórias, ficam também questionamentos: que concepções de corpo e de movimento estão prevalecendo nos programas de atividade física que se destinam à terceira idade? Estamos permitindo que os idosos "travem" a disputa subjetiva com o meio-ambiente e façam suas experiências? A Educaçāo Física é significativa? Corresponde aos desejos e necessidades dos idosos? A Educaçāo Física é simples atividade para ocupar tempo livre, prática sem reflexão? A Educação Fisica ed educaçāo? E meio ou tim qual sua especificidade? Que conteudos. objetivos e metodologia estāo permeando a Educaçāo Fisica na terceira idade? Qual sua legriminidade e identidade? Estào sendo despertadas/desenvolvidas as competencias necessúrias pura uma verdadeira qualidade de vida!

\section{REFERENCIAS BIBLIOGRÁFICAS}

ANDRADE, Carmem Maria, Velho e Sociedade. In: Caderno Adulto n.3. UFSM/ Santa Maria-RS, 1999

BARROS. Miryan Moraes Lins de (org). Velhice ou Terceira Idade? Estudos Antropológicos sobre identidade. memória e política. Rio de Janeiro: Editora FGV. 1998

BAECKER, Ingrid Marianne. A relação entre interesse, ação, produção do conhecimento, concepções de corpo e concepções de movimento. Texto produzido para a disciplina "Pedagogia do Esporte" do Programa de Pós Graduação em Ciência do Movimento Humano do Centro de Educação Física Desportos da Universidade Federal de Santa Maria, 1997

BEAUVOIR, Simone de. A Velhice. Rio de Janeiro: Nova Fronteira, 1990

BERQUÓ, Elza. Algumas consideraçōes Demográfica sobre o envelhecimento da População no Brasil. In: SEMINÁRIO INTERNACIONAL DE ENVELHECIMENTO POPULACIONAL. Anais, Brasília, 1996

BOTH, Agostinho et ali. Conversas sobre a Terceira Idade. Passo Fundo: EPU, 1991 . Fundamentos de Gerontogogia. Passo Fundo: EPU, 1994 Gerontogogia: educação e longevidade. Passo Fundo: Imperial, 1999

CEOLIN, Cláudia Elisa Grasel. Reflexões acerca da velhice, corporeidade, movimento e educação física. In: Caderno Adulto n. 3, UFSM/Santa Maria, 1999

- Universidade e Idosos - Mudanças de perspectivas através do contexto educacional. In: Caderno Adulto n. 4, UFSM/Santa Maria, 2000 
CHOPRA. Deepak. Corpo sem idade, mente sem fronteiras. São Paulo: Rocco, 1998

COSTA. Marisa Voraber (org). Caminhos Investigativos: novos olhares na pesquisa em Educação. Porto Alegre: Mediação. 1996

DEBERT. Guita Grin. A Reinvenção da Velhice: Socialização e Processos de Reprivatização da Velhice. São Paulo: EDUSP: FAPESP.1999 - As representaçôes (estereótipos) do papel do Idoso na sociedade atual. In: SEMINÁRIO INTERNACIONAL DE ENVELHECIMENTO POPULACIONAL. Anais, Brasília, 1996

DIAS, José Francisco Silva. Atividade Física na Terceira Idade. Santa Maria: Ediçōes UFSM, 1989

. Construindo a Velhice Consciente: Uma estratégia de parceira com a Educação. Tese de doutorado. Centro de Educaçâo/ Universidade Federal de Santa Maria. Sunta Maria. 1997

FERREIRA. Marcelo Guina, Teoria da Educução Fisica: Bases Epsitemologicas e propostas pedagogicals, In: BRACHT, Valter, NETO. A.. GOELLNER. S. (org). As Ciências do Esporte no Brasil. Campinas: Autores Associados, 1995

FERRI. Alceno. Uma perspectiva de Educação Permanente.Dissertação de Mestrado. Centro de Educação/ Universidade Federal de Santa Maria, Santa Maria. 1977

FREIRE, Paulo. Pedagogia do Oprimido. $17^{\mathrm{a}} \mathrm{ed}$. Rio de Janeiro: Paz e Terra. 1987 Pedagogia da Autonomia: Saberes necessários à prática educativa. $7^{\mathrm{a}} \mathrm{ed}$. Rio de Janeiro: Paze Terra, 1998

FURTER, Pierre. Educação e Reflexão. 16 ed. Petrópolis - RJ: Vozes, 1987

Educação e Vida. Petrópolis: Vozes, 1968

Grupo de Trabalho Pedagógico UFPe- UFSM. Visão Didática da educação física: análises críticas e exemplos práticos de aulas. Rio de Janeiro: Ao Livro Técnico, 1991

HILDEBRANDT,Reiner. Configuração Pedagógica do Movimento Esportivo no Ensino da Educação Física Escolar. In: Revista da Educação Física/UEM. Vol 1, n. I.Maringá-PR: Gráfica UEM, 1990

. Visão Pedagógica do Movimento. In: Revista da Educação Física/UEM. Vol 4, n. I.Maringá-PR: Gráfica UEM, 1993

KUNZ, Elenor. Educação Física: Ensino \& Mudanças. Ijuí-RS: UNIJUI Ed., 199| . Transformação Didático-Pedagógica do Esporte. Ijuí-RS: UNIJUI Ed., 1994

LÜDKE, Menga: ANDRÉ, Marli E. D. A. Pesquisa em Educação: Abordagens qualitativas. São Paulo: EPU, 1986 
MARQUES, Mario Osorio, Educação - Interlocução, aprendizagem-Reconstrução de saberes. Ijuí: UNIJUI. 1996

MARTINS de SÁ. Jeanete Liasch. Aluno Idoso no contexto universitário. Significado da sua presença. In: Revista Seminário Educação \& Terceira Idade: o envelhecer como processo de aprendizagem e experiência de vida. Textos, FUMEC, Belo Horizonte, agosto. 1999

MINAYO, Maria Cecília de Souza. (org). Pesquisa Social - Teoria, Método e Criatividade. $12^{2}$ edição. Petrópolis: Editora Vozes, 1999

MEIHY, José Carlos S. Bom. Manual de História Oral. São Paulo: Edições Loyola, 1996

MERLEAU-PONTY. Maurice. Fenomenologia da Percepção. 2ª ed Sāo Paulo: Martins Fontes. 1999

NER1. Anita Liberalesso (org). Psicologia do Envelhecimento: Temas relacionados na perspectiva de curso de vida. Campinas-SP: Papirus. 1995

OKUMA. Silene Sumire. O Idoso e a Atividade Física: Fundamentos e pesquisa. Campinas-SP: Papirus. 1998

POIRIER, Jean: CLAPIER-VALLADON, Simone: RAYBAUT, Puul. Histórias de Vida: Teoria e Prática. Oeiras: Celta Editora, 1995

RODRIGUES, Nara da Costa. A política pedagógica junto ao idoso. Revista Terceira Idade SESC. São Paulo, 1993

SANTIN. Silvino. Educação física: sabedoria de viver. In: Educação Física: Outros Caminhos. POA: EST/ESEF, 1993

ESEF. 1992

Educação Física: temas pedagógicos. Porto Alegre-RS: EST/

SOARES, Carmen Lúcia. Educação Física Escolar: Conhecimento e especificidade. In:

Revista Paulista de Educação Física. São Paulo, supl. 2, p. 6-12, 1996

THIOLLENT. Michel. Metodologia da Pesquisa-ação. 6ed. São Paulo: Cortez, 1994

TREBELS, Andreas H. Plaidoyer para um diálogo entre as teorias do movimento humano e as teorias do movimento no esporte. In: Revista Brasileira de Ciências do Esporte. Aprendizagem motora. Volume 13, número 13, junho/1992: 338 a 344. - Aprender a Movimentar-se- Pontos referenciais para uma teoria pedagógica do Movimentar-se. p 31-49. ANAIS-Seminário Brasileiro em Pedagogia do Esporte, Santa Maria - RS Brasil, 1998. Movimentar-se: aprender e Ensinar- Orientaçōes antropológico-fillosóficas.

P.135-147. ANAIS-Seminário Brasileiro em Pedagogia do Esporte, Santa Maria-RS Brasil, 1998.

VERENA, Alberti. História oral: a experiência do Cpdoc. Rio de Janeiro: FGV,1990 